University of Louisville

ThinkIR: The University of Louisville's Institutional Repository

\title{
An analysis of the methods used by John William De Forest in translating his personal war experiences into realistic fiction as shown in Miss Ravenel's conversion.
}

Elizabeth Maxwell Bright 1923-2010

University of Louisville

Follow this and additional works at: https://ir.library.louisville.edu/etd

Part of the Literature in English, North America Commons

\section{Recommended Citation}

Bright, Elizabeth Maxwell 1923-2010, "An analysis of the methods used by John William De Forest in translating his personal war experiences into realistic fiction as shown in Miss Ravenel's conversion." (1949). Electronic Theses and Dissertations. Paper 1921.

https://doi.org/10.18297/etd/1921

This Master's Thesis is brought to you for free and open access by ThinkIR: The University of Louisville's Institutional Repository. It has been accepted for inclusion in Electronic Theses and Dissertations by an authorized administrator of ThinkIR: The University of Louisville's Institutional Repository. This title appears here courtesy of the author, who has retained all other copyrights. For more information, please contact thinkir@louisville.edu. 
Univergity of Iouistille

An Analysis of the Methods Ueed by John W1lliam De Forest

In Translating His Personal War Heriences into Realistic

Mction As Shom in Mise Bavenel's Convergion

\author{
A Dissertation \\ Submitted to the Faculty \\ of the Graduate School of the University of Ioulerille \\ in Partial Fulfillment of the \\ Requirements for the Degree \\ of Master of Arts
}

Department of Thaliah

by

mizabeth Kaxwell Bright

Year

1949 
WAKT OP SPUDMNT:

TITIS OI THBSIS:
MLIZABENE MAXIKHLL BRIGHT

AN ANALYSIS OP TEE MGHHODS USTD BI JOEN

WILIAM DE TOREST IN TRANSIATING HIS

PHRSONAI WAR HXPTARTENCHS INTO RHAIISHIO

PICTION AS SHOWN IN MISS RAVMNTH'S

COUYRRSION

APPROVIHD BY RRADING COMITI COMPOSHD OI THA TOLLOWIHO MTHOBIRS:

Richard M. Kain

William F. Ekstrom

Mary E. Burton

NAME OP DIRDCTOR:

Mary E. Burton

DATB: May. 1949 


\section{TABIT OI CONTHAMS}

\section{Chapter I}

Introduction.............................

Chapter II

Biographical study of De Forest................9

Chapter III

Detailed Discussion of $A$ Volunteer's $\Lambda$ d-

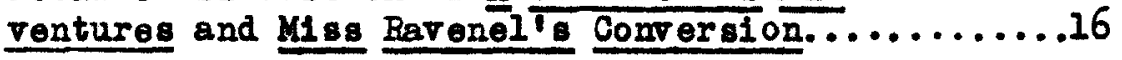

Chapter IV

Methods Used by De Forest in Translating

His War Mxperiences into Mction..............29

Chapter V

Conclusion...........................71 


\section{CEAPTER I}

\section{INTRODUCTION}

Daring the last half of the nineteenth century, novels, short stories, articles, and poems written by John William De Forest appeared in the pages of such popular magazines as Harper's, The Atlant1c Monthly, and The Gelaxy, along with literary contributions from Mark Twain, Whittier, Iongfellow, Henry James, and William Dean Howells. De Forest, however, has been forgotten by both the reading public and the literary historlans since that time, while the literary reputations of the other men have increased; yet it 18 to this obscure writer that modern critics such as Carl Van Doren, Alexander Cowie, Arthur Quinn, and Van Wyck Brooks have tarned in attempting to trace the growth of realigm in the American novel.

De Forest, born in 1826 and privately educated, travelled widely throughout Bhape and the Hear ast, returning to his native Connecticut to record his experiences in two trevel books. Besides these two books he had written prior to the Civil War two novels and a history of the Indians of his state. Unlike the other writers of this period, De Forest took an active part in the war, serving as a captain in the Union army for three years and an officer of the Freedmen's Bureau in South Carolina for three more. He recorded hio military experiences and impressions in the letters which he wrote to his wife and to other members of his famlly with the intention of collecting these letters and papers later and publishing them. 
He also found time to write articles describing his experiences which were published in the various literary magazineg of the day.

De Forest organized the unpublished letters and papers and the published articles into a manuscript which he hoped would be published in book form under the title, A Volunteer's Adventures. The material was to be divided into two parta: the first to be concerned with his active duty with the Union army, and the second to be concerned with his service in the Freedmen's Bureau. The second part carried a sub-title of The Bureau Kajor, and it has not been estab 11shed whether or not De Forest meant The Bureau Major to be published 1

as a separate volume. At any rate De Forest could interest none of the publishing houses in his manuscript which became part of the De Forest collection given to Yale University Library by his grandson, I. Effingham De Forest.

In 1946 the Yale University Press brought out A Volunteer's Adventures, edited with notes by James H. Croushore, and with an introduction by Stanley T. Williams. Two years later the same press published the second part of De Forest's manuscript, The Bureau Wajor, under the title, A Union Officer in the Recongtruction, edited with an introduction and notes by James H. Croushore and David Morris Potter.

De Forest's novel of the Civil War, Miss Ravenel's Conversion from Secession to Loyalty, was published in 1867 and ro-issued in 1939 , one of the best realistic treatments of the war up to that time, readable

1. See James E. Croushore, John William De Forest, A Biographlcal and Critical study to the Year 1868, unpublished doctoral dissertation, Yale University, New Haven, Connecticut, 1943, p.228 n. 
and entertaining to twentioth century readers.

Although De Forest devoted the rest of his life to his writing, especially to novels and short stories, he never gained recognition for his works in his own time or after the novel of realism was accepted by the American public; only in the last ten years has there been even an indication of a change in the attitude of the critics. Among the several critics who did attempt to awaken a negligent public during De Forest's life time were T. S. Perry and Clarence Gordon. Perry says of De Forest's novels as a whole:

H1s stories have certain undeniable merits, and if the great American novel needed only to be American, he would easily bear off the palm.l

Perry's attitude is clarified whon it is known that he felt that the best novelist was the one who could look at life and then idealize 1t:

He must idealize. The ldealizing novelist will be the real novelist. All truth does not lie in facts.2

Although Perry's stand was taken by the majority of critics who could appreciate what De Forest was attempting to do, Clarence Gordon was one of the few who praised his results. He writes in an article in The Atlantic Monthly:

[De Forest'g] strength is to observe closely, keenly, and humorously, and then recount easily, picturesquely, and conscientiously... In all

Mr. De Forest has written since the war, we

discern breadth, strength, and movement, wonderful honesty, freedom from prejudice, no

1. "American Novels," The North American Review, vol. cxv, October, $1872, \mathrm{p} .368$.

2. Ibid., p. 378 . 
affectation, very little exaggeration, and an entire absence of sentimentality...Moreover, there is a salubrious satire, a presentation of ourselves as others see us, freshening every page....Mr. De Forest is too honest to shirk the truth, from conventional delicacy.l

One other critic, and by far the most famous, sounded the praises of John William De Forest at the time when his novels were appearing before an unfriendly and even hostile public. This man was William Dean Howells, who as editor of The Atlantic Monthly, purchased mach of De Forest's work for publication in that magazine. Beginning in 1867 Howells applauded De Forest's literary works, giving them enthusiastic reviews in The Atlantic Monthly, sometimes writing special articles, and always mentioning De Forest when recounting his literary favorites. Howells felt that De Forest excelled in characterization, although he also adnired his humor, his dramatic faculty, and his vigorous style. Of one character in Kate Beaumont, Howells says:

It is so like a study from some actual character known to $\mathrm{Mr}$. De Forest, that we hesitate to credit him with its invention.2

"ISp far he is really the only American novelist," Howells said in his review of the Wetherel Affair.

Howells's praise received no more attention than did the novels of De Forest which he praised. After almost thirty years of champloning a man who seemed doomed to literary oblivion, he said in My Iiterary Pasaions:

1. "Mr. De Forest's Novels," The Atlantic Monthly, vol, xxx11, Hovember, 1873, pp. 611-21.

2. The Atlantic Konthly, rol, xxix, March, 1872, p. 365.

3. The Atlantic Monthly, vol.xxxiv, Auguat, 1874, p. 229. 
I have thought it more discreditable to our taste than to his talent that he has not been recognized as one of our foremost novelists, for his keen and accurate touch in character, his wide scope, and his unerring rendition of whatever he has attempted to report of American life; but I do not know that I shall ever persuade either critics or readers to think with me... [I]f I have never been able to make the public care for them as much as I did it has not been for want of trying.I

Recent interpretation of American literary history has served to bring De Forest to light once more, and mang well-known American critics have spoken in praise of De Forest and of his work, in attemptIng to give him belatedly his rightful place in the history of the development of the American novel. The re-issue of Miss Ravenel's Conversion by Harper's has also stimulated new interest and additional scholarship on De Torest and his work.

Van Wyck Brooks declares, "All in all, De Forest's work was a record of his time and country that should have aroused a more than passing interest." Carl Van Doren says, "The distinction...of writing the first American novel which may be called realistic in a modern sense belongs to John $W$. De Forest of Connecticut." ${ }^{3}$ In Iiterary History of the United States, George $\mathrm{F}$. Whicher writes:

De Forest was a pioneer realist too honest for his own good in an age that expected conventional falsifications In works of imagination... [T] he best of the Civil War novels and one of the most notable achievements in American flction is John William De Forest's Miss Ravenel's Conversion from Secession to Loyalty (1867), a book that for Iifelike portrayal of scenes of action, firm grasp of character values, and penetrating interpretation of

1. New York: Harper and Brothers, 1895, pp. 223-4.

2. New England: Indian Summer 1865-1915, New York; H. P. Dutton and Company, Inc., 1940, p. 242 .

3. The American Novel 1789-1939, New York: The Nacmillan Company, 1940, Revi sed Edition, pp. 117-8. 
the issues of the time can hardly be too highly praised.1

Unt1l $A$ Volunteer's Adventures was published in 1946 there was little opportunity to study De Forest's private papers and notes concerning either his ilfe experiences, his literary methods, or his personal feelings on either subject. That there is a con-

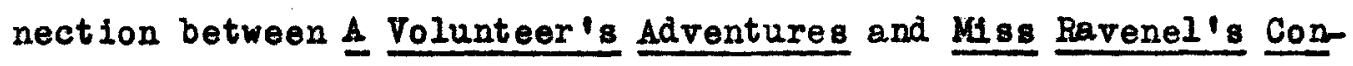
version is suggested by Stanley T. Williams in his introduction to De Porest's Civil War record:

Parallels between novel and journal are numerous: scenes, incidents, even phreses. It would be inexact to call the eloquent descriptions of war in the novel dress-versions of those in the journal; De Forest revised but seldom heightened this backdrop of death in life. In both a soldier is shot while drinking a mug of beer; in both we see the surgeons bending over the table in the hospital tent; in both are the same horrors, seen with De Forest's own eyes, and not to be repeated here. In the novel the sustained realism of the war eplsodes is enhanced by the slow revelation of Iillie Bavenel's tragic marriage to Colonel Carter, but the journal can boast its own virtues. Freed of all fictions, it registers the baptism (total immersion) of a soldier in battle, from ship Islend to the Shenandoah. Written in mudidy camps or on the fleld under the fire of the enemy, this is war itgelf.2

Following this suggestion the purpose of this study is to examine the methods which De Forest uses in translating his war experiences as noted in $A$ Volunteer's Adventures into fiction in Miss Ravenel's Conversion. The study of his methods will prove that, first of all, he used his actual reports and personal letters in writing the novel. This will be done by showing the similarity

1. R. R. Spiller and others, editors, New York: The Nacmillan Company, 1948, rol. 1 , p. 571.

2. A Volunteer's Adventures, pp. v1, vi1. 
between passages chosen from the two books and exhibited side by side. The comparison of the passages will also serve to point out that De Forest did not fictionallze the materials which he used, but reported as objectively in the novel as he did in the historical record.

Although this paper will not undertake to study the question of realism in De Forest's novels, it will show by inference that De Forest reported artistically exactly that which he observed, and as such should be declared a realistic writer. Mnally, this thesis will point out the fact that De Forest was somewhat lacking in imagination and that his best esset is his ablifty to observe shrewdy and make a written record of his ilfe experiences.

The method of studying De Foreat's translation of war experlences into fiction is a simple one. Parallel passages will be taken from the two books and catalogued as to the type of 11terary device which De Forest has used in making flction from non-fiction. The literary devices which have been used more than three or four times are letters introduced in the narrative as having been written by one of the principal characters, a paraphrase of letters supposedly written by one of the characters, reconstruction of scenes, roconstruction of events, report or summary by the author-reporter, conversation among the characters, combination of conversation and report by the author, the use of actual names of people, battles, and places, and the use of images and figures of speech first developed and used in the journal.

This paper will not be an attempt to compare De Forest with the 
other authors of the period; nor will it be an attempt to find De Forest's place in the literary hiatory of the advance of reallsm In the American novel. Rather it will be a concentrated effort to prove that Miss Ravenel's Conversion is an honest attempt on the part of De Jorest to describe life, especially during war time, as he saw it.

In studying De Forest's methods of translating his war experiences into realistic fiction, only the Civil War novel, Miss Ravenel's Conversion from Secession to Ioyelty, first edition, 1867, and the personal letters, articles, and papers published in book form as A Volunteer's Adventures will be used.

One of the greatest difficulties in working with De Forest is the dearth of material written about him. Only one complete biographical study has been written, an unpublished doctoral disser1 tation by James E. Croushore. Mrs. Joseph F. Jenovese (formerly Ann D. Carabillo) began a biography of De Forest and a study of his works in 1930 and worked on it for about elght years. The unpublished manuscript is at present a part of the De Forest collection at 2 Yale University. Although most of De Forest's novels are unobtainable in book form since they have been out of print since the time of intial publication, manj of them have been preserved as serials in some of the older magazines.

1. Tale University, New Haven, Connecticut, 1943. Mr. Croushore expresses the hope that he will be able to continue his investigations and publish in the near future a complete biography of John Wiliam De Forest.

2. Ibid., p. ix. 


\section{CEAPTIRR II}

\section{BIOGRAPHICAL STUDY OF DIR FORIST}

In order to show how De Borest's life experiences influenced his witings, and how he utilized his travels and trevel observations in writing his novels, it is necessary at this point to give a sketch of his 1ife. Accordingly, the following account will serve to show that De Forest's utilization of his experiences as a Civil War officer in the Union arny in writing his Civil War novel, Miss Ravenel's Conversion from Secession to Loyalty, is not a unique situation with him, as his other novels show that he wrote only of what he knew intirately, and utilized material he had collected first hand.

John William De Forest was born in Eumphreysv1lle, (now Seymour), Connecticut, on March 31, 1826, the son of John Hancock De Forest, a prosperous merchent and cotton manufacturer, and the former Dotha Woodward, daughter of mijah Woodward of Watertown, Connecticut. The De Forests were a Huguenot family, originally coming to this country in 1636 from Aresnes in French Hainaut.

The family planned to send John to Yale; howerer, because of his poor health and because of the death of his father in 1839 when he was but thirteen years old, the plans were abandonned. From this time on, De Forest's education was conducted privately, much of his study coming informally from trips abroad.

1. For this and receeding biographical detalls see James $B$. Croushore's unpublished doctoral dissertation. 
In 1846 he went to Beirut, Syria, where his brother, the Reverend Dr. Henry A. De Forest, a medical missionary, conducted a girls' school. For two years he travelled in the Near ast, returning to Connecticut in 1849 . He spent the next year working on his first book, A History of the Indians of Connecticut from the Earliest Known Period to 1850, published in 1851, an excellent piece of research standing today as an authoritative history.

In 1851 De Forest again went abroad, this time travelling extensively in Ingland, France, Germany, and Italy. Unlike the typical tourist, De Forest spent much of his time in Burope learning the customs, culture, and languege of the countries which he visited, matering Italian to the extent that he translated Hawthorne's The Eouse of Seven Gables into that language. While he was in Paris he became interested in Balzac, George Sand, and Stendhal, whose literary works were to have a profound influence on him later. After four Jears of Buropean travel, De Forest returned to Connecticut in 1855 and began his 11 terary career. His first novel, Witching Times, published serially in 1856 and 1857 in Putnam's Magazine, was an historical novel dealing with Salem, Massachusetts, during the witchcraft trials. Gordon Haight says in criticism that, although "the background of common life is created with well drawn details, the sentimental plot destroys what realism had been achleved 1

in the minor characters." In 1856 he also wrote and had published Oriental Acquaintance; or, Letters fron Syria, a travel book, based

1. Iiterary History of the United States, vol. 1i, p. 881 . 
on his experiences while in Beirut; and in 1857 he wrote Buropean Acquaintance, also a travel book, published in 1858. Both books were autobiographical and journalistic, giving an indication in his study of the people he met and especially of the antics and eccentricities of American tourists he chanced to observe, of the realistic tendency of his mind.

On June 5, 1856 he married Harriet Silliman Shepard, daughter of Charles Upham Shepard, an intelligent girl and considered an exceptional classical scholar of her day. For most of the next two years, they lived in Charieston, South Carolina, where Harriet's father was professor of chemistry at the medical college. Information concerning De Forest's family is exceedingly scanty, although it is known that a son was born to this union, Louis Shepard De Forest.

In 1859 De Forest wrote his second novel, Seacliff, a mystery tale with a tragic ending, of contemporary times concerning a forgery in which the heroine's mother was entrapped by a villainous lawyer in her youth, and a love-affair in which the young man cannot decide between mother or daughter. Cowie terms this novel "Somewhat trite in its action derices (including a plot to change a will), resourceful in 1 ts descriptions of daily life and in its portraiture of women..." The same year De Forest was awarded an honorary A. M. degree from Amherst College where his father-in-law served as professor of chemistry and natural history.

1. Alexander Cowie, The Rise of the American Norel, New York: American

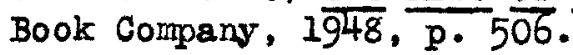


When Fort Sumter was fired upon, De Forest and his family were in Charleston, South Carolina, escaping to New Haven, Connect1cut, on the last boat leaving for the North. After the battle of Bull Run, De Forest recruited Company I, Twelfth Connecticut Volunteers, of which he was commissioned as captain on January I, 1862 , having gone into camp at Hartford, Connecticut, in the autumn of 1861. He served under Generals Phelps, Butler, Weitzel, and Banks In the Southwestern campaign, and under General Sheridan in Virginia and the Shenandoah Valley campaign. In December, 1863, he was made inspector general of the first division, Nineteenth Corps. In October, 1864, he was named chief of ordnance in the same division and shortly thereafter alde on the Nineteenth Corps staff. He was mustered out of service on December 2, 1864, his health broken by the humid climate of Loulsiana, the poor food, and the physical strain of living under war-time conditions. Almost immediately he returnod to New Haven to recuperate and to write his novel of the C1vil War, Miss Ravenel's Conversion, which he was to finish the next year.

Two months later, however, his application for admission to the Invalid Corps (later re-named the Veteran Reserve Corps) was accepted, and he was commissioned as captain by an order signed by President Andrew Johnson and E. M. Stanton dated May 7, 1865, the captaincy to date from February 10, 1865. Assigned to Company I, Fourteenth Regiment, he was stationed at Washington, D. C., and a few months later was made chlef of the Veteran Reserve Corps office. On way 15,1866 , he was brevetted major, the rank to date from 
March 13, 1865, for "gallant and meritorious services during the war." 1

The Veteran Reserve Corps was disbanded in July, 1866, and De Forest was assigned to the Bureau of Freedmen and Refugees; and on October 1, 1866, he took charge of the Bureau district of Greenville and Pickens counties. Anderson County was added to his district later. De Forest was finally mustered out of milltary service in January, 1868. He returned to New Haven, Connecticut, and spent the rest of his life in pursuing a literary career.

After the publication of Miss Ravenel's Conversion in 1867 , which will be discussed in detail later, he wrote Overland, which was published serially in The Galaxy from August, 1870, unt1l July, 1871. This novel, an adventure story with a setting in the Southwestern states and the Grand Canyon, was criticized by William Dean Howells for the reason that the cruel and dishonest figures "are hardly balanced by the good people of the story."

The following year Eate Beaumont was serialized in The Atlantic Monthly from January to December, 1871. A satire, this novel deals with Southern customs and conventions, especially the tradition of dueling, and has for a background, Charleston, South Carolina. The plot centers around a feud between the families of the hero and heroine. Howells, in praising Kate Beaumont, atates that this novel is "strong proof that we are not so much lacking in an American novelist as in a public to recognize him. ${ }^{3}$

1. A Volunteer's Adventures, p. xviil.

2. The Atlantic Monthly, vol. xxix, January, 1872, p. 111.

3. The Atlantic Monthly, vol. xxix, March, 1872, p. 365. 
The Wetherel Affair (1873), a murder-mystery, was followed by two political satires-Honest John Vane, serialized in The Atlantic Monthly from June to November, 1873, and Playing the Mischief, (1875). Both novels were set in the era following the CIvil Var, and both took place in politically corrupt washington, $D$. C. Tallerton says that these two books are "perhaps the first believable pictures of everyday American politics in our literature." ${ }^{1}$ Howells, who remarks, "The wife of Honest John Vane 1 s pitilessly ascertained, and there is a widow in 'Playing the Mischief' who is not a mirror for widows, to say the least, " commends the former book by proclaiming, "In this country, at least, there has never been so good a political satire as this..."

Justine's Lovers (1875) was concerned with a woman's attitude toward marriage. Irene the Missionary (1879) was the story of a missionary school at Beirut, Syria, in which De Forest utilized material he had collected while visiting his brother. The Bloody Chasm, or The Oddest of Courtships, published in 1881, deals with Charleston, South Carolina, during the Reconstruction perlod, the plot centering around a Southern girl and her Tankee hasbend, with whom she refuses to $11 \mathrm{ve}$. In 1898 De Forest tried to reach a reading

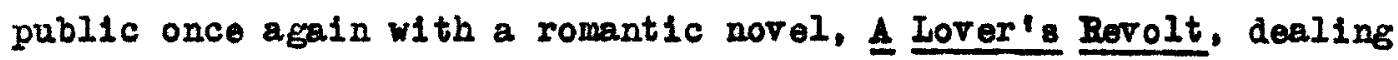
with Boston during the Revolutionary War, although this book fared no better than the others.

1. Selective B1bliography of American Iiterature 1775-1900, Now York; Dial Press, 1936, p. 82 .

2. Herolnes of Hction, New York: Harper and Brothers, 1901, vol. 11, p. 157 .

3. The Atlantic Nonthly, vol. xxxv, February, 1875, p. 238. 
Besides the many short stories and articles which De Forest contributed to The Atlantic Monthly, The Galaxy, Harper's Monthly, and other magazines, he wrote poetry, collecting and publishing his poems in two books, The Downing Legends, (1901), and Medley and Palestina, (1902). He also wrote a history of his family, The De Forests of Avesnes and New Netherland, (1900). De Forest collected his letters and articles written during and concerning the Civil War, and arranged them in book form, as has been said before. A Volunteer's Adventures was finally published in 1946 , and $\mathrm{A}$ Union Officer in the Reconstruction in 1948.

De Forest died in Hew Haven on July 17, 1906, disappointed and slightly bitter because of his failure to gain literary recognition. 


\section{CEAPTIR III \\ DHFAILAD DISCUSSION OF A VOLUNTEER'S ADVBRTURES \\ AND MISS RAVBNRL'S CONV BRSION}

When De Forest was with the Nineteenth Corps, he was assigned in October, 1864, to the task of writing the accounts of the battles in which the Corps was engaged. Although there is no more definite proof than this knowledge, James H. Croushore feels that De Forest's accounts of the battles of the Opequon and of Cedar 1 Creek were part of this assignment. At any rate, these two narram tives, along with "The First Time Under Fire," which was first published in Harper's Monthly, September, 1864, "Forced Marches," first published in The Galaxy, June, 1868, and "Port Hudson," first published in Harper's Hew Monthly Magazine, Augrast, 1867, were revised by De Forest later, probably in the $1880^{\prime} \mathrm{s}$, and prepared for publication in book form.

At the same time he collected letters which he had written to his wife and to other correspondents, and began to write new material from selections from these letters. He also wrote a synopsis of his military record. By 1890 the manuscript of his Civil War experiences was completed under the title of A Volunteer's Adventures. Although it is not certain whether or not De Forest over offered his manuscript for sale to any publisher, it was not published during his lifetime; and first publication came in 1946 when James

1. See $\underline{A}$ Volunteer's Adventures, $p p . x i$ and $x 11$. 
H. Croushore edited the manuscript for the Yale Untversity Press. The book contains fourteen chapters, each dealing with a different phase of his military Iife. De Forest wrote a preface for the volume, giving a resumé of his service career, and concluding with the following remarks:

The letters printed in this volume were mostly to my wife. Of course many more were written, but a certain number have naturally di sappeared, and others were mere scraps on ammuntition paper, etc. Those here included might hare been reduced to a narrative; but it seems to me that they show camp Iife clearly and naturally; hence I leave them as they are.1

However, considering the nature of De Forest's novel about the Civil War, Misg Ravenel's Conversion, it is a question whether or not the last part of this statement can stand unchallenged.

Upon his discharge from the Union army on December 2, 1864, De Forest returned to New Haven to convalesce from what he thought was a chronic illness. As De Forest attests, "It was during this period of invalidism that I wrote Mlss Ravenel." "The novel was completed, however, while De Forest was on active duty in the Veteran Reserve Corps Bureau in Washington, D. C.

In December, 1865, Harper and Brothers bought the novel from De Forest for $\$ 1,250$ : Negotiations were in process between the author and the publisher since October of the same year, De Forest holding out for ownership of the copyright, and spurning the one thousand dollars first offered by Harper's. The agreement finally signed by De Forest surrendered complete ownership to the publisher,

1. A Volunteer's Adrentures, p. xriil.

2. Ib Id., p. xvis. 
and stipulated that the novel was to be published serially with 1llustrations in Harper's New Monthly Magazine. Harper's also had the privilege of publishing the manuscript in book form for their exclusive profit. On December 28, 1865, De Forest sent his manuscript off by express.

Publication was delayed, however, since Harper's hesitated in publishing what was sure to be controversial reading matter in their magazine. A new contract was finally drawn up on october 27, 1866, an agreement to bring out the manuscript in book form. A copyright was granted Harper's on March'25, 1867, and the first copy was printed May 31, 1867 . 1

It was soon apparent that Miss Rarenel's Conversion was one of the biggest fallures in American publishing. The regult was naturally disappointing to De Forest, and he re-wrote parts of the novel, deleting many of his asides and caustic renarks concerning the frailties of human nature in general and women in particular, attempting twenty-one years later to have Harper's bring it out again in its revised edition. He was doomed to disappointment, however, and it was not until the realistic novel held a secure place in American fiction that Harper and Brothers, upon the urging of Carl Van Doren, again published M1ss Ravenel's Convergion. This edition appeared in 1939, nearly three-quarters of a century after its 2 initial publication.

1. See Croushore's unpublished doctoral dissertation.

2. The 1939 edition does not contain all of De Forest's corrections. For example, Harper's chose to include the chapter headings which De Forest evidently decided to omit. See Croushore's dissertation for more details concerning this edition. 
Miss Ravenel's Conversion has fared better at the hands of modern critics, hovever. In his introduction to $\mathrm{A}$ Volunteer's Adventures Stanley T. Williams says that Miss Ravenel's Conversion

...is a living book; rediscorered, it may go on to even greater distinction in the history of the American novel. The modern reader, after the first amusing shock at the contrast to the techniques of his own era, respects more and more the integrity of De Forest's reali sm...I

Another book reviewer judges the novel

One of the best war stories in U. S. fiction, the first and one of the best realistic portraits of a young American girl, the slyest commentary on the difference in romantic Southern and Northern ways of doing the same thing...2

Cowie declares that the novel "has finally come into its own as a substantial social document and as a literary production of far more than average merit in its period." 3

Carl Van Doren, one of Miss Ravenel's staunchest supporters, who states that "no other novel of the decade has been less dimmed by a half century of realism," describes the book as

Coldly truthful in its descriptions of battles and camps, crisp and pointed in its dialogue, penetrating, if not over-subtle, in its character analysis, sensible in its plot and in its general temper,... almost as convincing as it was once precocious. 4

Gordon Haight expresses the same feeling of admiration:

Instead of a chivalrous romence of Blue and Gray, De Forest tells of the wearisome struggle against mud, filth, sickness, stupidity, red tape, and graft. Fear and panic, the anguish with which the bravest face battle, such horrors as the field hospital are all described uncompromisingly. 5

1. P. vi.

2. "Rebel Romance," Time, vol. xuxiv, August 21, 1939, p. 57.

3. The Rise of the American Novel. p. 514 .

4. The American Novel, p. 118 .

5. Iiterary History of the Untted States, vol. 11, p. 882. 
These rodern critics are saying essentially what William Dean Eowells tried to tell an indifferent reading public half a century ago. In his review of Miss Ravenel's Conversion, Howells complains that "the heroes of young-lady writers in the magazines have been everywhere fighting the late campaigns over again, as young ladies would have fought them," adding, "Mr. De Forrest [sic] is the first to treat the war really and artistically." In My Iiterary Passions he says further that this is "the best novel suggested by the civil War. If this is not saying very much for Miss Ravenel's Conversion, I will go farther and say it was one of the best American novels that I had known, and was of an advanced realism, before realism was known by name."

The plot of the novel is a falrly simple one. Niss Lillie Ravenel and her father, Doctor Renel, have lately left their home in New Orleans for New Boston in the state of Baratariam-a very thin disguise for New Haven, Connecticut--because of the outbreak of war. Dr. Ravenel, a physiclan, has been a professor of theory and practice in the Medical College in New Orleans, and is now trying his hand as a mineralogist. Although he was born in South Carolina and has lived in the South most of his Iife, his sympathies are with the Federal government. Politically, then, he is at odds with his seventeen-year-old daughter, who is a rabid secessionist.

Iillie, a blue-eyed blonde, is not beautiful. De Forest says

1. The Atlantic Monthly, vol. xx, July, 1867, p. 121.

2. Op. cit., p. 223 . 
on this score:

It is curlous how resolutely most persons demand that the heroine of a story shall be extraordinarily handsome. And yet the heroine of many a love affair in our own lives is not handsome; and most of us fall in love, quite earnestly and permanently in love too, with rather plain women. Why then should I strain my conscience by asserting broadly and positively that Miss Ravenel was a first class beautyil

What IIIlie may have missed in the way of beauty, she makes up for in esprit and charm, as the main conflict in the novel concerns the rivalry of two men for her hand.

In the early pages of the story the Ravenels chance to meet Mr. Idward Colburne, a native New Bostonian, and Ileutenant Colonel Carter, a Virginian and West Point graduate on furlough from his post in Louisiana. Colburne, a sensitive and bashful young lawyer, cannot compare with the dashing officer in Llllie's eyes, for Colburne, she feels, is not magnetic. Colonel Carter, on the other hand, is, despite the indications of a dissolute and dissipated iffe, self-possessed, bold, and raggedly handsome. He is not seriously interested in the young lady, since she is penniless and has no prospects of regaining any of her lost Southern property; but always attracted by women, he feels her charm. Colburne, however, immediately falls in love with her and begins a rather bashful and

1. New York: Harper and Brothers, 1867, p. 13. De Forest changes this passage in the revised edition to read: "As to her being as lovely as a hourl, there were different opinions on that question, the general rule being that those who knew her best were most likely to think her handsome." See the revised edition of Miss Ravenel's Conversion, New York: Harper and Brothers, 1939, p. 6. 
bungled sort of courtship.

When Carter has to return to his regiment in Louisiana a short time later, Lillie is distressed. Colburne recruits a company of volunteer soldiers soon after the Battle of Bull Run, and as captain of the company, leaves also for Louisiana. He promises to write, and does throughout the book.

It is not surprising that the Ravenels also return to Louisiana, New Orleans to be exact, after the Union army has captured the city and established military control of it. Carter is made mayor of the city, and the Ravenels soon fenew their acquaintanceship with him and with Captain Colburne who is also stationed there. Mrs. Larue. Iillie's young and beautiful French Creole aunt and next door neighbor, also makes the acquaintance of the two officers.

Colonel Carter befriends the Doctor, offering him several positions, one of which the latter accepts. Eventually Carter falls in love with Lillie, who accepts his proposal of marriage. Both Dr. Ravenel and Colburne are much distressed at this turn of events, since neither one feels that carter could make her a good husband. De Forest adds his opinion:

I always agreed with her father in preferring Colburne, whose character, although only half developed in consequence of youth, modesty, and Puritan education, is nevertheless one of those germs which promise much beauty and usefulness.1

The marriage takes place before Colonel Carter leaves for fleld duty, and upon his departure Dr. Ravenel and Lillie take over a

2. P. 243 . 
plantation in the interests of educating the Hegro. It is to this plantation thet Captain colburne comes to recuperate after being wounded in the first assault of Port Eudson; and when some of Greene's Texans are reported advancing on this locality, he aids them in evacuating to Fort Winthrop.

At this point, Carter, who has been named military governor of Loulsiana, sends for his wife, and for a time the couple live very happily at Thlbodeaux where Carter establishes his headquarters. The Colonel applies for a leave of absence shortly thereafter in order to go to Washington to see about his getting a deserved and long awaited promotion. He not only wishes the added prestige of being a brigadier general, but he also is in need of the extra pay. The awarding of promotions to undeserving men for political reasons 1s taken up by De Forest as a secondary theme in the novel, his contention being that men such as Colonel Carter and Captain Colburne who fought valiantly in the field would not be a party to the political bickering found in the War Department.

As chance would have 1t; Mrs. Lerue is on the same steamer as Carter. She exerts her wiles on him, giving hin to understand in no uncertain terms that she would welcome hin as a lover. She says:

Do you know what is left to a woman thenl sither hidden love, or spiritual self-murder. Which is the greater of the two crimes? Is the former a crime? Society says so. But are there not exceptions to all rules, even moral onesil

1. P. 378 . 
In the end the Colonel succumbs to Nirs. Iarue's advances, at the same time suffering greatiy from remorse when he remembers his innocent, trusting wife. Curiously he feels that the greater fault lies with Mrs. Larue. "A woman in the same house has so many devilish chances at a fellow," he says to himself bitterly. In his absence Iillie, who is to have a child, goes to live with her father in New Orleans, as it is lonely in the little cottage in Thibodeaux and she wants companionship. Upon the return of the lovers to Now Orleans, they continue their illicit affair undetected, Krs. Iarue often' going to the Colonel's office at night to be with him. When Lillie's son in born, howerer, Mrs. Larue is the stronger of the two as it is she who decides that the affair must end.

Finding himself in financial difficulties and no promotion in sight, Carter makes the mistake of using government funds, and in trying to extricate himself from this blunder, he finds himself involved in another shady deal to defraud the governmont. Dr. Ravenel discovers Carter's falthlessness and perfidy, and by accident Lillie learns of 1t, too. Broken by the news, she leaves New Orleans for the North and sends a message to her husband that she does not want to see hin again.

The note reaches carter on the eve of the battle of Cane River. Faten by remorse for what he has done to her, and equally fearful of discovery in his manipulation of government books, he is personally distraught; yet, thoroughly an officer, he leads his men brilliantly into battle, taking the objective at the cost of his life. Mortally 
wounded he refuses the administerings of the army chaplain, and is buried with honors by his regiment. When the news reaches Iillie, she says:

"I am so sorry I quarreled with him. I wish I had written to him that I was not angry."I

Colburne, the young man who did not speak French, "nor any other modern language;... [who] did not draw, nor sing, nor play, and was in short as destitute of accomplishments as are most Ameri2

cans," returns after his discharge from the army, wooes the young widow, and finally wing her hand. Enthusiastic about living in New Fngland now, Miss Ravenel has undergone a complete conversion to Yankee sentiments.

Although the story concludes with a happy-ever-after ending, the reader is not assured that this is true. Lillie does not seen to be any more taken with Colburne than she was in the beginning; she is more interested in providing her son with a home and flower garden. As the author points out:
At last Colburne had his wife, and his wife had her home...
It grieves me to leave this young woman thus on the threshold of her history. Here she is, at twenty-three, with but one child, and only at her second husband. Two-thirds of her years and heart history are probably before her. Women are most interesting at thirty...3

Upon close examination it will be found that there are similarities between A Volunteer's Adrentures and Miss Ravenel's Conversion in three different fields. First of all, there are

1. Pp. 459-60.

2. P. 181 .

3. P. 519. 
similarities in characters which appear in the novel and in the journal. Second, there are identical backgrounds in the two books. Third, there are indisputedy similar incldents occurring in both the novel and the historical record.

The most obvious oimilarity in character, other than the use of actual and famous men, is between Captain Colburne, and the author, John W1lliam De Forest. Both were handsome captains who recruited a company of volunteers and led them in the Louisiana and Virginia campaigns. Both enlisted after the battle of Bull Run and were discharged the winter of 1864-65, with health impaired. The military experience of each of the two men differs in very few instances, and these instances would seem to have occurred because of mechanical changes in the plot of the novel. Both men served under Generals Weitzel, Banks, Butler, and Fhelps. Both suffered only one minor wound during the entlre period of field duty.

The instances of similarity are mumerous, and there is little doubt in the reader's mind that De Forest, whether unconsciously or not, was describing himself when he wrote of Hdward Colburne. Howerer, the attempt to prove that Colonel Carter is also a character drawn from a life model, is not so easy. Carter resembles General Phelps, one of De Porest's superior officers, in many respects. Both are sticklers for drill, regimentation, and rigid discipline. Both are true soldiers. Yet there are differences, such as personal appearance and amount of education, between the two men. Several speeches of Carter's are similar, however, to speeches of Colonel Deming, who is mayor of New Orleans. Carter is also named military 
mayor of New Orleans and governor of Loulslana. At other times Incidents accredited to unnamed officers in De Forest's journal are described as happening to Carter. Thus it would appear that Carter is not a character drawn from one particular person whom De Forest knew, but from many of these men. He is a composite of the gentleman-officer type of men whom De Forest knew and fought with during the war.

De Forest's father-1n-law, Charles Upham Shepard, bears a remarkable likeness to Lillie's father, Dr. Ravenel. Shepard, a cousin of Ralph Waldo Imerson, was professor of chemistry at the Medical College in Charleston, South Carolina, and, at the same time, professor of chemistry and natural history at Amherst. He was also internationally known as a geologist, and in South Carolina founded the phosphate industry. Although this biographical data, 1

gathered by James H. Croushore, 1s the only evidence of this similarity, the suggestion has been made by Cowle that Shepard has, indeed, been "presumably drawn upon for some details in the portrait of Dr. Ravenel in Miss Ravenel's Convergion."

De Forest has used the names and characters of actual men participating as leaders of the Union and Confederate armies. He Introduces them, however, into the novel no more than he does in his personal account. In other words, he makes not the slightest attempt to do as so many other novelists do-use a nationally

1. A Union Officer in the Reconstruction, p. xvil.

2. The Rise of the American Fovel, p. 505 . 
known figure in order to provide atmosphere or background for the story.

The backgrounds of the two books are even more noticeably simllar. Although De Forest, for political ressons, declines to name Connecticut and New Haven and, instead, calls them respectively Barataria and New Boston, still there is no doubt in the reader's mind of what state and city he is speaking. The cities of New Orleans, Thibodeaux, Alexandrla, and the like which are the settings for parts of the novel, are likewise the cities about which De Forest wrote his war commentarles. 'Battles, such as the one at Georgia Ianding, Port Hudson, Jort Jackson, and Cedar Creek, are mentioned in both narratives. It can be stated without risk of being challenged that there is no place mentioned or described in Mige Ravenel's Conversion which is not also mentioned or described in $\mathrm{A}$ Volunteer's Adventures.

The third field of similarity between the two books lies in the plot incidents which seem to have been lifted bodily from the historical record made by De Forest and altered enough to make them conform with his plot scheme before belng placed in the narrative of the novel. Of this type of likeness there are many concrete examples. However, this subject will be treated by inference in the next chapter, the subject of which is the study of the methods by which De Forest translates these incidents from his letters or articles into story form. 
CEAPTIHR IV

MENHODS USFD BY DI MOREST IN MRANSIATING HIS KAR EXPPHIIRTCISS INTO PICTION

One of the derices most often employed by De Forest to incorporate parts of his Civil War letters and articles in his novel, Miss Ravenel's Conversion, is that of having Kiss Ravenel or her father recoive letters written by the two Civil War officer8, Captain Colburne and Colonel Carter. As Captain Colburne bears a remarkable 11keness to author De Forest, it is understandable that most of the fictitious letters are ascribed to the captain. Colburne might also have been selected by Do Forest to be the exponent of objectivity in viewing war and wartime conditions and to write home letters describing war from this viewpolnt, since ho has a different attitude toward war from the Colonel.

Colonel Carter is a West Pointer and a man hardened and conditioned by war. As has been suggested in the previous chapter, the character of carter is most probably drawn from a man or a composite of men whom De Forest personally knew during his military career. Carter as a regular army man is not conceivably able to view the situation objectively as De Forest himself saw 1t first hand, and Captain Colburne, the younger of the two men, a rolunteer, and a never completely militarized civilian, would logically have the fresher point of rlew. At any rate, despite 
the author's reasons, only two or three of the Colonel's letters contain excerpts from De Forest's papers.

The letters of the two character primarily serve three purposes. Mrst of all, the letters are used as a means of portraying the feelings and reflections of men in a war situation. The norelists of this period often used letters as a means of giving the reader this type of information, and De Forest was no exception. De Forest, howerer, did not use this device to the exclusion of others. Hls characters are often given to reflective thinling, and one of the most delightful points about his novels is his interpretive commentary on character and character motivation which mans throughout this work. The following excerpt from one of his articles reads:

While we awaited the order to set forward I studied with interest the physiognomies of our men. They had by this time quite lost the innocent, pacific air which characterized them when they entered the service. Hardened by exposure and suffering, they had a stony, indifferent stare and an expression of surly patience, reminding me of bulldogs and bloodhounds held in leash. It was impossible to dirino from their faces whether they expected battle or a peaceful march.1

This material becomes a reflection of the hero in the novel:

It wa a long row of stern faces, bronzed with sunburn, sallow in many cases with malaria, grare with the serious emotions of the hour, but hardened by the habit of danger, and set as firm as flints toward the enemy. The old innocence of the peaceable New Bngland farmer and mechanic had disappeared from these war-seared $\nabla 1$ aages, and had been succeeded by an expression of hardened combativeness, not a little brutal, mach like the look of a lazy bull-dog. Colburne smiled with pleasure and pride as he glanced

1. A Volunteer's Adventures, p. 108. 
along the line of his company, and noted this change in its physiognomy.1

However, it is more usual for De Forest to use letters in order to portray the feelings and commentaries of his characters on the subject of war.

Second, De Forest used the letter device in order to relate incidents which are of interest to the reader in setting the mood or establishing a convincing background, and which may or may not bear a direct connection with the plot.

Third, the letter enabled the author to telescope eventa and summarlze happenings occurring over long periods of time, thus prerenting a drag in the movement of the plot action.

De Forest's reaction to seeling the rounded men about him on the field of bettle can be used to 1llustrate this point. In the journal he says:

One man was borne past us with both his feet shot off about midway, and the bare spikes of bone protruding white and aharp from the bloody flesh... [A] color corporal near me dropped his masket and spun around with a broad stream of blood dribbling down his face. I supposed for a moment that he was a dead man; but the ball had merely ran along the upper edge of his leathern forepiece, driving it through the okin; there was nothing worse than a shallow gash from temple to temple.

He was stunned and blinded, however, and fell against a sergeant who stood near him. The sergeant laid him down, and then suddenly reeled against me, his face as white as if he vere mortally wounded. I helped him to a stump, asked him where he was hurt, and found he was merely faint. There mast be somethine infectious in swooning, for of a sudden everything swam around me, and I had to draw long breaths to steady myself. In all my days under fire I never but this once had such a ridiculous and contemptible moment...2

1. M1ss Ravenel's Conversion from Seccession to Loyalty, p. 279. 2. $\overline{\mathrm{Pp}}$ 109-10. 
The identical incidents are reproduced in M18s Ravenel's Conrersion:

When one of our men was borne by me with half his foot torn off by a round shot, the splintered bones projecting clean and white from the ragged raw flesh, I grew so sick that perhaps I might have fainted if a brother officer had not given me a sip of whiskey from his canteen. It was the only occasion in my fighting experience when I have had to resort to that support. I had scarcely recovered myself when I say a broad flow of blood atream down the face of a color-corporal who stood within arm'g-length of me. I thought he was surely a dead man; but it was only one of the wonderful escapes of battle. The bullet had sldrted his cap where the fore-plece joins the cloth, forcing the edge of the leather through the skin, and making a clean cut to the bone from templo to temple. He went to the rear blinded and with a smart headache, but not seriously injured."I

De Poreat manages to accomplish two things by means of

this fictitious letter: he gires details which enable the reader to visualize the situation, and he expresses Colburne's and his own lmmediate reaction and commentary on the sight of the wounded. This passage gives the reader background by means of a few concrete details.

Another illustration might serve better to show De Forest!s use of the letter in order to express a soldier's opinions and feelings concerning the war situation. In one of his letters to his wife, De Forest says:

The heat is tremendous. Fles are thicker than in Ingpt, and mosquitoes thicker than in Guilford. But it is astonishing how healthy and contented our bronzed reterans are. They build themselves hovels of rails and boards, bake under them like potatoes

1. P. 283. 
in hot ashes, and grumble at nothing but the lack of tobacco. A soldier is not a hero in fighting alone; his patience under hardahip, privation and sickness is equally herolc; sometimes I feel disposed to put him on a level with the martyrs.l

Colburne simflarly writes:

"Three months without shelter, drenched by rain or scorched by the sun, tormented by mosquitoes, talnted with ferer, shaking with the ague, they appear stolcally indifferent to all hardships but their lack of tobacco... Oh, these noblemen of nature, our American common soldiers! In the face of suffering and of death they are my equals; and while I exact their obedience, I accord them my respect." 2

The comments on war incidents of a regular army man differ from De Forest's, and it is interesting to note that he also includes opinions from this type of man in having the heroine read letters from Colonel certer. In his article on Port Hudson published in $A$ Volunteer's Adrentures, De Forest mentions an incident occurring in that battle which he presents in a light, bantering manner since in reality the accident did not prove fatal:

... I said to the commandant, Lieutenant Clark, "What a palace you hare left mel"

"It looks nice," replied clark, smiling doubtfully at the newly built green shanty which he was about quitting. "But it isn't all my fancy painted 1t. I had scarcely got comfortably settled in it and commenced reading a newspaper when a bullet went through the leading editorial."3

Colonel Carter reports the same incident in a letter to his wife; and although his remarks reflect the same manner as did De Forest's, in this version of the story the bullet found its mark:

1. P. 151.

2. P. 362 .

3. P. 119 . 
"I had just finished breakfast, and was lying on uy back smoking. A bullet whistled so unusually Iow as to attract attention and struck with a loud smash in a tree about twenty feet from me. Between ae and the tree a soldier, with his great coat rolled under his head for a pillow, lay on his back reading a newspaper which he held in both hands... Presently I noticed that there were a few drops of blood on his neck, and that his face was paling... The ball had struck him under the chin, traversed the neck, and cut the spinal column where it joins the brain, making a fearful hole through which the blood had already soaked his great-coat. It was this man's head, and not the tree, which had been struck with such a report. Where he lay, st112 holding the New York Independent, with his ejes fixed on a sermon by Henry Ward Beecher." 1

By means of the letter device, De Forest gives the reader a sense of the times by describing scenes and incidents as seen through the eyes of his character and reported by them. When De Forest's regiment first arrived at New Orleans, he wrote:

Apparently this paradise had been nearly deserted by Its inhabitants. Betreen Fort Jackson and Chalmette, a few miles below Hew Orleans, we saw hardly fifty white people on the banks, and the houses had the look of having been closed and abandoned... The roughs, the low women and the ragged urchins continue to hoot, jeer, swear and call us evil names.... red-nosed man, addreasing me personally, declares with many oaths, "We don't want you here, damn it l You haven't come among friends, not by a damn sight... We wouldn't give you a cup of water." 2

Two weeks later, De Forest writes home again:

There was an almost continual mutter of "Damn Yankees" from the row of ugly, dirty, viclous faces whlch surrounded our pen...

The poverty of the once flourishing city of New Orleans is astontshing. I have seen nothing like

1. Pp. 302-3.

2. $\mathrm{Pp}$. 17-8. 
Its desolation since I quitted the deserted street of Ventce, Terrara and P1sa. Almost the only: people visible are shabby roughs and ragged beggars.1

Captain Colburne's regiment also arrives in New Orleans, and he writes to Miss parenel:

"We are in New Orleans... the first to reach the city and to witness the bareness of the oncecrowded wharves, the desertion of the streets and the sullen spite of the few remaining inhab1tants. I suspect that your aristocratic acquaintances have all fled at the approach of the Vandal lankees, for I see only negroes, poor forelgners, and rowdies more savage-looking than the tribes of the Bowery. The spirit of impotent but impertinent hate in this population is astonishing. The ragged news-boys will not sell us a paper... Wherever I walk I am saluted by mutterings of 'Damned Yankeel' -' Cut his heart out I'..."2

Throughout the journal, De Forest mentions food, usually taking a paragraph or so each time to describe its quantity, quality, and kind. More often it is the lack of food which De Forest describes, for he soon becomes used to makding a meal of hardtack and salt pork. In his comments on food the reader again gets an impression of war. To his wife, De Forest relates in a letter:

No money yet; our paymaster reached Donaldson ville the day after we left; and now we shall get nothing till the road is open between here and New Orleans. I came uncomfortably near starving on the Crescent. Two borrowed dollars were all that I had for the royage, and the meals at the cabin table were fifty cents each. The first day I had breakfast and supper, going without dinner. The next day I had breakfast only; the third day I had dinner only. Then came twenty-four hungry hours during which I ate nothing but a slice of

1. Pp. 20-1.

2. $\mathrm{Pp} \cdot 124-5$. 
watermelon given me by another officer. The men were on half rations, or I might have begged some hardtack of them... When I reached shore I could hardly utter an order and was in very poor condition for Ilghting, if we had found any. My first meal here, foraged I don't know how by man Goorge, was a tin plate full of fried ontons, and nothing else. You can't imagine how delicions and restorative I found it.I

Colburne similarly says:

I think that the sererest trial I ever had was on a transport. The soldiers were on half rations; and officers, you know, must feed themselves. We had not been pald for four months, and I commenced the royage, which was to last three days, with seventy-fire cents in my pocket. The boat charged a quarter of a dollar a meal... The first day I went without breakfast and supper. On the morning of the second day I awoke fearfully hungry, and coold not resist the folly of breakfast. I had character enough to refuse dinner, but by night I was starving again... I ate supper. That was last possible meal on board the steamer. I had no chance of borrowing, for every one was about as poor as self...[A] brother officer produced a wermelon wich he had sared for this supreme moment of destitution. He was charitable enough to diride it among four fellow paupers; and on that quarter of a watermelon I lived twentyaix hours, very wretchedly. When we landed I was In command of the regiment, but could hardly give an order loud enough to be heard by the shrunken battallon. Two hours afterwards Henry brought me a small plate of stewed onions..." 2

In one letter, De Forest telescopes the events which occurred during the campalgn at Braghear City. The following summary he wrote in one of his own letters:

Kany of our fellows are trying to forget their illnesses and miseries in Algerlan whiskey; for swanp ferer has turned our ine regiment into a sickly, dispirited, undisciplined wreck. Owr service at Brashear City was not a rest; it was

1. P. 151.

2. Pp. 360-1. 
picket duty against an enemy within striking distance; what was far worse, it was within range of country fever. Forty-two deaths in fortytwo days; barely two hundred and twenty-five men left for duty; and most of those staggering skeletons covered with fever sores; if they were at home they would be in bed and asklng the prayers of the congregation.l

He synopsizes a period of at least two months in this passage in the norel:

"Out of the four hundred men whom we brought to this poisonous hole [Brashear City], forty are dead and one hundred and sixty are in hospital. We can hear their screams a mile away... The remalnder, half sick themselves, thin and yellow ghosts in ragged.uniforms, crawl out of their dimimutive shanties and go calmly to their duties wthout murmuring, without a desertion." 2

One letter occurring in Miss Ravenel's Converaion seems to serve all three purposes, in that it gives an excellent account of the sentiments of the soldiers, it helps to establish a comvincing background, and it condenses a long period of time and relates in a brief space, erents which do not further the plot, but which are of interest to the reader. It is interesting to note that De Forest chose to summarize the action of a battle, of which he had no written record. The letter he originally wrote describing the attack of Fort Jackson was lost by the time he finily collected his materials for $A$ Volunteer's Adventures. 3 A later letter alludes to the bombardment of Fort Jackson, in which he sags:

2. P. 154 .

2. P. 362 .

3. See note, p. 14. 
I shall probably astonish you when I say that we did not find the bombardment magnificent nor eren continuously interesting. It was too distant from us...We could hear a continuous uproar of distant artillery; we could see clouds of smoke curling up from behind the leafage which fringed the river...Also, if we climbed up to the crosstrees, the forts were visible beyond a forested bend...

We smoked and read novels; we yawned often and slept a great deal; in short, we behaved as people do in the tediums of peace; anything to kill time... Now and then a blazing fireship floated by us, lighting red the broad, sulf, sublime river, and glowing away southward.

At last came a story that Farragut had run the forts, and we had one day of excitement, expectetion, anxiety. Daring the late evening a submerged hulk, which some one guessed was the Rebel ram Manassas, drove agalnot our iron cable, tearing It down through the hawsehole... If the wreck had not been fended off by the cable, if it had struck one of its angles into our wooden bows, we should have gone to the bottom through one hundred and fifty feet of water. This was our one noteworthy alarun and danger during the whole siege.l

The version in the novel is strikingly similar:

"Here we are, in view of what I am told is the greatest bombardment known in...amphibious warfare. You take it for granted, I suppose, that we are in a state of constant and noble excitement; but the extraordinary truth is that we are In a condition of wearisome ennui and deplorablo desaeurrement... We got tired a week ago of the mere aurlcular pleasure of the incessant bombing. We got tired a day or two afterward of climbing to the crosstrees to look at the fading globes of smoke left aloft in the air by the bursting shells...We pass our time in playing cards, smoking, grumbling at our wretched fare, exchanging dull gossip and wishing that we might be allowed to do something...

Whe fleet has forced the passage of the forts. We have had a day and a night of almost creay excitement...A submerged iron-clad, one of the

1. $P$ p. 14-5. 
wrecks of the enemy's fleet, drifted against our cable, shook us over the edge of eternity, and then floated by harmlessly. Blazing fire-ships have passed us, lighting up the nidnight river until its ripples seemed of flame."I

As used by De Forest, the letter proves to be a very effective device. He informs the reader of the situation at at least two different geographical points-the home of Miss Ravenel, the heroine, and the campaign area of colburne, the hero, and that of Carter, the villain. Far more important, however, is the background or mood these letters create. There is a feeling of honest reporting in Captain Colburne's remarks to his friends in these letters, an effect accomplished in part by reason of the fact that De Forest allows little fictionalization to creep into the first-hond material he is using. There are numerous 11lustrations of the lack of fictionelizing in De Forest's transfer of material from his papers to his novel. However, since this aspect is imediately apparent in every single excerpt quoted above in comparing the original source and its novelistic counterpart, no further examples of this quality of De Forest's writing are necessary at this time.

Less frequently De Forest uses the device of paraphrasing letters supposedly written by his characters. The purposes of this measure seem to be to summarize particular stretches of time which are not desired in the plot of the novel, and to describe events taking place in areas which are not mentioned

1. P. 123 . 
in the norel.

In $\frac{\hat{A}}{1}$ Volunteer's Adventures De Forest spends five chapters in recounting camp life and battle activity in Virginia, especially at Cedar Creek, Virginia, and the Shenandoah Valley. In Miss Ravenel's Conversion he says: ... Colburne's letters vere her [M1ss Rarenel's] chlef social pleasures...

In July (1864) they heard that the Nineteenth Corps had been transferred to Virginia, and during the autumn Colburne's letters described Sheridan's brilliant victorie in the shenandoah Valley. The Captain was present in the three pitched battles, and got an honorable mention for gallantry, but no promotion... More than two-thirds of the rank and flle, and more than two-thirds of the officers had fallen in those three savage atruggles. Nevertheless the young man's letters were unflagging in their tone of elation...2

Chapter $\nabla$ of De Forest's journal concerns the winter of 1862-63, and is entitled "Turther Camp Iffe in Louisiana." Although some of this material is used in various places in Miss Ravenel's Conversion, the main erents can not be successfully used in this novel, and the import of this chapter is summarized in the novel by referring to letters from Captain Colburne which are not reproduced verbatim:

Nothing of interest happened to hin [Colburne] during the winter, except that he accompanied his regiment in Weitzel's adrance up the Teche, which resulted in the retreat of Mouton from Camp Bearland, and the destruction of the rebel iron-clad "Cotton." A narrative of the expedition, written with his usual martial enthusiasm, but which unfortunately I have not space to publish, was receired by Doctor Ravenel...3

1. Chapters X-XIV, pp. 159-232.

2. Pp. 471-2.

3. P. 225 . 
While De Forest was in Virginie, he referred many times In his letters to the lack of food and to the hardshtps thus encountered by both officers and men. In one of his letters published in $\triangle$ Volunteer's Adventures he relates:

It was Sunday, and as we tramped through Georgetown and down Penngylrania Arenue, we were stared at by swarms of people... At this halt I was lucky enough to borrow half a dollar from a brother officer and got a lunch in a corner bakeshop. It was the first food that I had had in twenty-four hours except one hard biscuit.l

Less than a month later, De Forest writes to his wife:

Near us are Hunter's and Crook's troops... both in a fagged-out and demoralized condition, ragged, famished, discouraged, sulky, and half of them in ambulances... For ten days they have not had a rest of four hours at a time, and very rarely a chance to cook their ratlons. Crackers and raw pork have been thelr main diet, and hardly ever enough of those abominable refreshments. Of course thl is nothing strange In war; our own men meanwhile have had no meat for four days; only crackers and coffee. And the officers, being without pay and with out a chance to forage, live on green apples or other such deleterious provender. 2

In the novel this material is used in the following manner:

It appears that these little starvation eplsodes were of frequent recurrence. In one letter he [Colburne] speaks of having marched all day on a single biscuit, and in another, written during his Virginla campalgn, of having lived for elghteen hours on green epples. He often alluded with pride to the hardihood of soul which privations and dangers had given to the soldiers.3

1. Pp. 161-2.

2. Pp. 163-4.

3. P. 361 . 
Although De Porest as novelist does not paraphrase letters as often as he reproduces the letters themselves, still this device is used on enough occasions to warrant notice of it. This method 18, perhaps, not so effective as the use of the letters themselves, but it proves to be adequate for De Forest's purposes.

A third device De Forest uses in translating his personal experiences into material for his novel is that of reporting or summarlzing events through the eyes of an observant author. These expository passages seem to serve three purposes. IIrst of all, De Forest can summarlze events and incidents not necessary to the action of the novel but which are of interest to the reader. Second, he can describe Captain Colburne in an objective way and at the same time give his own sentiments on the military. Third, he, in reporting objectively, can make the action run more smoothly. De Forest uses a rather familiar style in these passages, often using the pronouns "I" and "we" in the narration of events.

The description of the arrival of Captain Colburne at Ship Island is by no means necessary to the plot of the norel, since nothing of consequence occurs during this period of the young hero's career. In order to introduce the reader to army routine and army conduct of affairs, however, De Forest briefly summarizes the Ship Island meuvers. According to De Forest's letters, he landed on Ship Island on March 15, 1862. 
He describes this area in one of the earlier letters pub-

11shed In Chapter. I of $\Delta$ Volunteer's Adventures:

Ship Island is the sandiest region this side of the Great Sahara. Sullivan's Island... is a spot of verdure in comparison. Here the sand is of a dazzling white which glitters in the moonlight like snow, and by day dazzles and fatigues the eyes unless the weather be cloudy.l

The rest of Chapter I continues the description of the erents which De Forest summarizes in this passage from M1ss Parenel's

\section{Conversion:}

One summer-like March morning the steam transport, black with men, lay bowing to the snow-like sanddrifts of Ship Island; and by sunset the regiment was ashore...

It is well known that the expedition against New Orleans started from Ship Island as its base. Over the organization of the enterprise, the battalion and brigade drills on tho dazzling sands, the gun-boat fights in the offing with rebel crafsers from Mobile, the arrival of Parragat's frigates and Porter's bomb-schooners, and the grand review of the expeditionary force, I must hurry without a word of description, although I might make up a volume on these subjects from the new spapers of the day, and from three or four long and enthusiastic letters which Colburne wrote to Ravenel.2

Another example, however, 1llustrates De Forest's familiar atyle better than the foregoing one. When De Forest was near Thibodeaux in the late fall of 1862, he wrote back to his wife:

It is woful to see how this lately prosperous region is being laid waste. Negroes and runaway soldiers roam everywhere, foraging for proviaions, breaking into and plundering the deserted houses,

1. P. 3 .

2. Pp. 121-2. 
and destroying furniture, books and pictures in mere wantonness. If the planters had remained, they would have been furnished with military guards and would have fared much better. The blacks have the credit of doing most of the looting, and they in turn are looted by the mauvais sujets of the rank and file. Testerday colored servant George brought in ten pounds or so of solid old table silver. I had no means of restoring it to the owner, who had followed Mouton with all his family; so I simpliffed the situation by telling George to clear out with it and never let me see it again.l

De Forest begins Chapter XVI of Miss Ravenel's Conversion by saying:

After the victory of Georgla Landing, the brigade was stationed for the winter in the vic intty of the little half-Creole, half-American city of Thibodeaux. I hare not time to tell of the saclding of this land of rich plantations; how the inhabitants, by flying before the northern Vandals, induced the spoliation of their own property; how the negroes defiled and plundered the for saken houses, and how the soldiers thereby justified themselves in plundering the negroes; how the furniture, plate and libraries of the Iafourche planters were thus scattered upon the winds of destruction.2

These two comparative examples, then, show De Forest's familiar style as the author-reporter, summarizing events which are not necessary to the plot, but which make interesting reading and which better acquaint the reader with the Louisiana situation.

One of De Forest's most impressive descriptions is the one of Captain Colburne as a battle-worn combatant. The description follows carefully the materlal which De Forest noted in his letters and articles in describing himself. After the battle of Port fudson he wrote to his wife:

1. Pp. 73-4.

2. P. 218 . 
You can hardly imagine how unclean and how ragged our regiment is, officers as well as soldiers. On all sides I can see great patches of bare skin showing through tattered shirts and trousers. I have but one suit, and so cannot wash it. My pantaloons will almost stand alone, so stiff are they with a dried mixture of dust. mad, showers, and perepiration.

I look forward with longing unutterable to the day when I shall be able to substitute decent clothing for the whole foul encumbrance.1

A year later while he is in Virginia, De Forest writes home:

If you could see me, dirty from head to foot with marching, my unform a common soldier's blouse and trousers, my hat so ragged that it does not even keep out the sun, you would not blame your correspondent's laxity.2

The description of Colburne is much like it journalistic source:

He is dark-red with sunburn; gaunt with bad food, irregular food, fasting and severe marching; gaunt and wiry, but all the hardler and stronger for 1t, like a wolf. His coarse fatigue uniform is dirty with sleeping on the ground, and with marching through mud and clouds of dust. It has been soaked over and over again with rain or peropiration, and then powdered thickly with the fine-grained, unctuous soil of Louisiana, until it is almost stiff enough to stand alone. He cannot wash it, because it is the only suit he has brought with him, and because moreover he never knows but that he may be ordered to fall in and march at 11ve minutes' notice.3

A description of the common soldiers is particularly well done, and this description also is reported by De Forest as the observant authox. De Forest had sald in his article on forced marches:

1. Pp. 148-9.

2. P. 169 .

3. P. 276. 
In describing the miseries of marching, I must not forget the dust. The movement of so many thousands of feet throws up such dense and prodigious clouds that one who has not witnessed the phenomenon will find it difficult to imagine It in all its vastness and nuisance. The officers dodge from side to side of the road to escape the pulverous suffocation; and the men, bound to their fours, choke desperately along in the midst of it. The faces become grimed out of all human semblance; the eyelashes are loaded, the hair discolored, and the uniform turns to the color of the earth. It frequently happens that you cannot see the length of your regiment, and it has occurred to me that I have been unable to see the length of my own com peny of perhaps twenty files.l

The version in the novel is again very similar to the original description quoted immediately above. It reads:

It was through an atmosphere of scalding heat and stifling dust that the brigade marched up the bluffs of Bayou Sara and over the rounded emin ences which stretched on to Port Hudson. The perspiration which drenched the ragged uniforms and the pulverous soll which powdered them rapidily [sic] mixed into a mudy plaster; and the same plaster grimed the men's faces out of almost all semblance to humanity, except where the dust clung dry and gray to halr, beard, eyebrows and ejelashes. So dense was the distressing cloud that it was impossible at times to see the length of a company. 2

A final example of De Forest's objective descriptions of Colburne as representative of the feelings of the officers and men marching in the Louisiana Teche country is derived from this excerpt from his article:

Oh, the horrors of marching on blistered feet!... Heat, hunger, thirst, and fatigue are nothing compared with this torment. When you stand, you seem to be on red-hot iron plates; when you walk, you make grimaces at every step. 3

1. Pp. 95-6.

2. $\mathrm{Pp} \cdot 277-8$.

3. F. 92 . 
Of Colburne, De Forest says:

He has borne as well as the hardiest mason or farmer those terrific forced marches which have brought the army from Camp Beasland to Alexandria on a hot scent after the flying and scattering rebels. His feet have been as sore as any man's; they have been blistered from toe to heel, and swollen beyond their natural size; but he has never jet laid down by the roadside...l

A third regult of De Forest's objective reporting as the observant author is that of aiding the progress and tempo of the action. In Kiss Ravenel's Conversion, for example, the hero is wounded in the bettle of Fort Winthrop and does not see action at Port Hudson as the result of this wound which requires hospltalization. The plot, hovever, has been bullding up to the coming battle at Port Hudson as a decisive factor In the Southwest campaign, and thus the author is obliged to tell the reader of the outcome of this engagement. De Forest accomplishes this in a single, if very lengthy, paragraph. Hil original account which appeared in the August, 1867 issue of Harper's New Monthly Magazino, and which takes up two long chapters in his journal, contains innumerable incidents which De Forest utilizes in other parts of the novel and attributes to other campaign areas.

The condensed version is singularly well done. It is compact, and yet the details are sharply enough defined for the reader to get a complete and clear cut plcture of the scene of the Port Hudson battle. In part De Forest says:

1. Pp. $276-7$. 
When Colburne reached Port Hndson, it had capitulated; the stars and stripes were flying in place of the stars and bars. With a smile of triumph he climbed the steep path which zig-zagged up the almost precipitous breast... of the gigantic bluff which formed the river front of the fortress... Not a sign of fortification was visible, except five or six small semi-lunes of earth at different polnts along the edge of the bluff, behind which were mounted as many monstrous guns, some smoothbore, some rifled. Solid shot from these gients had sunk the Mississipp1, and crippled all of Farragut's fleet but two in his audacious rugh up the river. Shells from them had flown clean over the bluff, and sought out the farthest camps of Banks's army, bursting with a sonorous, hollow thunder which seemed to shake earth and atmosphere... The turf was torn and pitted by the bombardments; two-hundred-pound ahalls, thrown by the long rifles of the fleet, lay here and there, some in fragments, some unexploded....

Similarly, De Forest records in $\triangleq$ Volunteer's Adventures

a long and detalled account of the Union plan to surround the

Southern forces at Camp Bisland near Pattersonville, and

of the fallure of that plan because Grover, a brigadier general

In the Union army, "unacquainted with the country and ordered to the wrong plece...had gone to the wrong place." ${ }^{2}$ In the novel De Forest summarizes the objectives and the results of this part of the campaign in one paragraph, concluding with the following remark:

But for somebody's blunder at that well-named locality, Irish Bend, the plan would have succeeded better than it did, and Taylor would not have been able to reorganize, take Brashear City, threaten New Orleans, and cone near driving Banks from his main enterprise.3

\footnotetext{
1. $\mathrm{Pp}_{\mathrm{p}} \cdot 346-7$.

2. P. 91 .

3. P. 278 .
} 
One final example should be given to illustrate De

Forest's wide use of the device of the author-reporter in

order to utilize his personal war experiences in writing

fiction. De Porest, writing a letter from New Orleans, says:

I saw last evening something very curlous and interesting to me. I saw a new race; a race which is seeking to win a respectable footing in human society; a race which holds such a footing in thrope though scorned by us. One of our lieutenants... fell ill a few weeks since and was sent to a city hospital, not far from the barracks of one of Butler's newly raised colored regimenti.l

De Forest as novelist seems equally taken with these people:

[I]n the Crescent City and in some of the richest planting districts of Loulsiana... you will find a class of colored people, who are not black people at all, having only the merest fraction of negro blood in their yeins, and who are respectable in character, numbers of them wealthy, and some of them accomplished. These Creoles, as they call themselves, have been free for generations, and until Anglo-Sax on law invaded Louisiana, enjoyed the same rights as other citizens. They are good Cathollcs; they marry and are given in marriage; their sons are educated in Paris on a perfect level with young Frenchmen; their daughters receive the strict survelliance which is allotted to girls in most southern countries. In the street my of them are scarcely distingul shable from the unmixed descendants of the old French planters. But there is a social line of demarkation drawn about them, like the sanitary cordon about an infected district.2

A fourth device which De Forest uses quite often is that of having his characters report information, war in cidents, war-time conditions, and events to each other in

1. P. 47 .

2. Pp. 183-4. 
confersation. The purposes of this method are obvious.

Conversation is a natural medium to impart information. Conversation, if correctly used, also keeps the action moving, and can make the material contained in the convergation seem more realistic or corpatible with dally life. A half dozen examples of De Forest's use of conversation in order to utilize incidents and events which happened to him personaliy In the Southwest campaign should suffice to prove this point. Several times in the record of his war activities, De Forest mentions Ceneral Phelps's connection with the colored reginent 8. In July, 1862, he writes:

As to the Negroes, they are all on our side, although thus far they are mainly a burden. In apite of indirect discouragements they are contimally quitting the plantations and swarming to $u s$ for protection and support. Ifeutenant Potter, our brigade provost marshal, has on his roll seren hundred of them, all living in or about the camp and drawing rations. Potter wishes they were on the coast of Gulnea, and sulkIly asks General Phelps what he shall do with them.

"I don't know," squalls the brigadier, as much bothered by the "inevitable nigger" as if he were not an abolitionist. If he had his own way, doubtless, he would ralse black battalions....

Two months later he sajs:

Five hundred Negroes arrived with the Baton Rouge colum; and they drift hither in gangs every day from the plantations... Pifty or sixty good tents have been furnished to a large squad which General Phelps has cominenced drilling. Rations are issued to all, and a roll of names is kept by our provost marshal, who is amusingly "sick of niggers."2

1. P. 31 .

2. P. 39 . 
One of De Forest's characters in Miss Pavenel's Conrersion, Major Scott, claims to be one of the Negroes who enlisted in this colored reginent. At one point in the marrat1ve Mejor Scott forms the plantation Negroes into two ranks:

"I knows how to form "em," he said with a broad smile of satisfied vanity. "I used to c'mand a comp'ny under Gineral Phelps. I was head boss of his cullud 'campment. He fus' give me the title of Major."

He took his post on the right of the line, honored the Doctor with a military salute, and comanded in a hollow roar, "Tentionl"l

In one of his letters. De Forest describes a Union adjutant's house, appropriated from a wealthy Rebel captain, and remarks on the wine situation:

The cellar is well stocked with madeira and burgundy, some of the vintages being twenty years old, if one may credit the involces. As there was no champagne in it, the adjutant plundered two other private wine cellars, one of them belonging to Soulé... He told me that in one day he and his friends drank forty-six bottles.2

De Forest develops an amusing and interesting character, Ileutenant Van Zandt, in the novel, who is much given to heavy drinking. Upon one occasion he is living in a house which he, like the adjutant, has appropriated for his and Captain Colburne's quarters, and he is entertaining $418 s$ Ravenel's father. De Forest records the following conversation in atilizing the information quoted above:

"Nearly dinner time, sir," he said in a rolling deep tone like mellow thunder. "The Captain w11l

1. P. 263 .

2. P. 50 . 
be in soon for that good and sufficient reason... Give you some capital wine, sir, out of Monsieur Soulé's own care...

He commenced rummaging among papers and writing materials with an exhilaration of haste which caused Ravenel to suspect that he had taken a bottle or so of the Soule' sherry.l

And later, Van Zandt says:

"We have derilish fine times here, sir...We finished the rebel captain's wine-cellar long ago, and are now living on old Soulés. Imptied fortysix bottles of madeira and champagne yesterday. 2

De Forest seemed to have been much impressed with the striking poverty of New Orleans. Several times in each of the two books he mentions the destruction of the plantations, the desertion of the once-busy wharres, and the impending starvation and destitution of the inhabitants. One particular passage from his account he inserts into the novel in the form of conversation. In 4 Volunteer'g Adventures this passage appears as:

The porerty of the once flourtining city of New Orleans is astonishing. I have seen nothing like its desolation since I quitted the deserted streets of Venice...

Unless work is soon found for these people, I do not see how famine can be averted. Flour ranges from twenty-three to thirty dollars a barrel; Irish potatoes, elght dollars a bushel... The country people charge us ten cents a quart for milk and seventy-five cents a dozen for eggs...

of course these prices represent the depreciation of Confederate money as well as the scarcity of merchandise. 3

Dr. Ravenel volces much the same sentiments:

"But what a cityl I must break out with my amazement. Who could have believed that prosperous,

1. P. 128 .

2. P. 130 .

3. P. 21 . 
gay, bragging New Orleans would come to such grlef and povertyl... Business gone, money gone, population gone."1

The manner in which De Forest as novelist first describes the attitude of men in their initial battle is interesting as he does this by means of conversation and prediction. The peculiar disposition of the men to fire and reload and fire again without regard for a target was noted by De Forest in an article he wrote for the September 1 save of Harper's Monthly, also published in

\section{A Volunteer's Adventures:}

The men could not watt to fire by file, which is a graduated discharge running from right to left of each company; they leveled those five hundred rifles together and sent a grand, crashing rolley into the hostile line of smoke which confronted them; for as yet we could see no other sign of an enemy. In the next second every one was loading his piece as if his life depended on the speed of the operation. Then of a sudden, to my utter amazement, the two centre companies fell on their faces.2

In the novel, Colonel Carter talks with Captain Colburne, describing mach the same sort of thing in anticipation:

"I know what he'll do when he comes under the eneny's fire. He'll blaze away straight before him as fast as he can load and pull trigger, he'll be in such a cursed hurry to kill the men who are trying to kill him. I couldn't probably make him fire right oblique, if I wanted to... It's really amusing to notice how eager and savage new troops are. The moment a man has discharged his plece ho falls to loading as if his salvation depended on 1t. The moment he has loaded he fires just where he did the first time, whether he sees anything or not." 3

1. P. 135 .

2. P. 64f.

3. P. 196. 
In the fall of 1862 an incident happened to De Forest which mast have made a profound impression on him, as he mentions the incident in different forms no less than four times. It 1s interesting to note that in three of the four times, the incident is related in the form of conversation. De Forest narrates the occurrence to his wife in a letter dated October 10, 1862:

I mat tell you of an adrenture of mine with one of the heroines of secession. On my way down to the city in the crowded, dirty cars, I saw behind me, standing, a lady in half-mourning, a pallid and meagre young woman, with compressed thin lips, sharp grey eyes and a waspish expression. Mach doubting whether my civility would be well recelved, I rose and offered her my seat. She would not look at me; she just conceded me a quick shake of the head and a petulant shrug of the shoulders; then, pinching her pale 11ps, she stood glaring straight before her.

After waiting her pleasure a moment I resumed my seat. Presentiy a rather pretty lady opposite me...took her little girl into her lap and beckoned the scowling heroine to the vacant place. She accopted it with lavish thanks, adding in a loud, ostentatious tone, "I wasn't going to take a seat from a Yankee. These cars used to be a fit place for ladies. Now niggers and Yankees crowd decent people out." I

The first time De Forest introduces the incldent into the narrative of the novel, the incident is given from the viewpoint of the "heroine of secession," or, in this case, the "herolnes of secession." Mrs. and Miss Langdon call apon Lillie Ravenel's aunt when Iillie is present. De Forest begins by giving Miss Bavenel's opinion:

1. P. 51. 
She actually felt inclined to laugh satirlcally when the two risitors proceeded to relate jointly and with a species of solemn ferocity how they had that morning snubbed a Yankee officer.

"The brute got up and offered us his seat in the cars. I didn't look at him. Welther of us looked at him. I said-we both said--'We accept nothing from Yankees.' I remained-we both remained--standing." Such was the mild substance of the narrative, but it was horrible in the telling, with fierce iittle hisses and glares, sticking out from it like quills of the fretful porcupine.1

Upon the departure of these two ladies, Dr. Ravenel enters and tells his daughter:

"I have seen a couple of officers shamefully insulted to-day by a woman who calls horself a lady. They returned not a word, not even a look of retaliation."2

Whether this conversetion referred directly to the same incident of being refused upon offering a lady a seat on the street car, the author does not say. However, when Captain Colburne calls upon Miss Ravenel several hours later, the original story is told again, this time from his, the offended officer's, viow point:

"I am sorry to say," he cont inued, "that most of the ladies of Hew Orleans seom to regard us with a perfoct hatred. When I pass them in the street they draw themselves aside in such a way that I look in the first attainable mirror to see if I have the small-pox... I was dreadfully set down by a couple of women in black this morning. They entered a street car in which I was. There were several citIzens present, but not one of them offered to give up his place. I rose and offered them mine. They no more took it than if they knew that I had scalped all their relatives. They surveyed me from head to foot with a lofty scorn which made them seem fifty feet high and fifty years old to my terrified optics. They hissed out, 'We accept nothing from Yankees,'

1. Pp. $145-6$.

2. P. 147 . 
and remained standing." 1

The last time De Forest mentions the incident, he 18 describing New Orleans prior to the battles of the Teche country: Pale brunette ladies flouted their skirts scornfully at sight of Federal uniforms, and flounced out of omnibusses and street cars defiled by their presence. 2

Sometimes De Forest uses a fifth derice of combining conversation with his own report as observant author. The reasons for doing this are also obvious, as conversation and observance by the author are two widely used literary devices; and thus it is impossible to suggest any reasons why De Porest chose these particular mediums for ingerting naterial from his letters and articles into his novel, since they are purely literary devices. At any rate, four examples will serve to lllustrate De F'orest's use of this method.

At various points in both books, De Forest mentions colored troops or the possibility of ralsing them. Several of these passages have been quoted previously in this chapter, especially concerning General Phelps's interest in the Negro as a soldier. At one time, however, De Forest himself became interested in leading one of these black regiments, and wites the following b1t of news to his wife:

Do you fancy the idea of my applying for the colonelcy of a colored regiment I Important people here advise it and promise to help me with recommendations. It would be a comfortable position, I suppose; but there are some obvious serious disadrantages. The colored troops will probably be kept near here and used to garrison unhealthy positions; they will be called on for fatigue duty, such as

1. Pp. 153-4.

2. P. 198. 
making roads, building bridges and draining marshes; they will be seldom put into battle, and will afford small chance of distinction.l

In the same letter. De Forest says:

Since writing the above I have talked on the subject with Colonel Deming, who is acting mayor of New Orleens and well informed concerning affairs at headquarters...

"I advise you," aid ha. "not to make your proposed application, for fear it might be successful." Then he went into details concerning the character of the officers who would be associated with me, and the nature of the service that will be assigned to the Negro troops, which detalls I do not feel free to repeat. In short, he counselled me so urgently against the step that I have given it up and decided to fight my way on in the Twelfth, if it is ever to have any fighting.2

Captain Colburne undergoes a similar experience which is related partly by the author-reporter, and partly by conversation:

I consider it worth while to mention here that Colburne committed a great mistake about this time in declining a regiment which the eldest Meurice offered to raise for him, providing he would apply for the colonelcy... He took the proposition into serious consideration and referred it to Carter, who advised him against 1t...

"I may be all wrong," he admitted with a considerable effusion of swearing...."I despise the low brute. I hate to see him in uniform. And then he never will be used for the higher military operations. If you take a command of niggers, you will find yourself put into Fort Plke or some such place, among the mosquitoes and fever and ague, where white men can't live. Or your regiment will be made roadbullders, and scavengers, and baggage guards, to do the dirty work of white regiments." 3

One of the most interesting observations concerning the Creoles which De Forest makes upon meeting the Dumas family

1. Pp. 50-1.

2. P. 51 .

3. Pp. 189-90. 
while in New Orleans, is inserted in Miss Ravenel's Conversion by the same method of a combination of conversation and author's report. In his letter to his wife, published in $\mathrm{A}$ Volunteer's Adventures, De Forest reports:

One of our lieutenants... asked me to join him at an entertainment given by a wealthy business man named Dumas, whose brother is captain in the First Colored and will be major of the Second. The ladies were very pretty, he said, and had not a trace of the African in their faces... At Dumas' house we found six other officers, three of them from white regiments and three from colored. Oar entertainer is a man of about thirty who looks like a West Indian; his brother has the complexion of an Italian and features which remind one of the first Napoleon. Both of them, although natives of New Orleans, have spent a great part of their lives in Paris, and speak good French, but nothing else. They did not differ in air and manners from the young Frenchmen whom I used to know abroad... The supper was a collation of cakes, confectionery, creams, 1 ces and champagne, followed by café noir, cognac and deliclous cigars.1

The fact that Captain Colburne also visits a Creole family as their dinner and evening guest several times causes a scene when Miss Ravenel learns of it. That De Forest found the Creoles an interesting race with an unhappy problem is shown not only in the remarks he makes in Chapter III of $\mathbb{A}$ Volunteer's Adrentures quoted previously in this paper, but also in the fact that tho scene mentioned above covers at least half of Chapter XIII in Miss Ravenel's Conversion.

The discussion of the Meurice family is carried on by $D_{0}$ Forest by means of both objective description and conversation

1. $P p \cdot 47-8$. 
among the several characters. The author says by way of preliminary explanation:

Now these white negroes...constituted the sole loyal class... which Butler found in Louisiana... Foremost...were two brothers of the name of Meurico, who poured out their wealth freely to meet those incidental expenses, never acknowledged by Government, which attend the recruiting of volunteer regiments... The joungest Heurice became Major of one of the regiments, which I take to be the nearest approach to a miracle... Their entertainnents became so famous that invitations to them were gratefully accepted by officers of Anglo-Saxon organizations. At their profuse yet elegant table... Colburne had. met...even stray Marylanders and Kentuckians. There he became acquainted...with the tasse de cafe nolr and the petit verre de cognac which close a French dinner. There he smoked clgars which gave him new Ideas concerning the value of Cuba.l

At this point Mrs. Larue acquaints Miss Ravenel and her guests with the facts which the author has been relating to his reader. "Ce sont des mét1s, chère," she laughingly tells Miss Ravenel, whose reaction is related by the author:

Iillie colored crimson with amazement, with horror, with downright anger. To this New Orleans born AngloSaxon girl, full of the pride of lineage and the projudices of the slaveholding society in which she had been nurtured, it seemed a downright insult that a gentleman who called on her, should also call on a metis, and admit it and defend it.2

Colburne calmly defend his Creole friends, as in the following excerpt from h1s long dialogue:

"I don't hesitate to call them nice people. As for the African blood in their veins (if that is a reproach) I can't detect a trace of it. I

1. Pp. 184-5.

2. $\mathrm{Pp} \cdot 185-6$. 
shouldn't have believed it if they hadn't

as sured me of 1 t...

"When I first saw the eldest Meurice," he

proceeded, "I supposed from his looks that he

was a German. The Major bears a striking resemblance

to the first Hapoleon, and is certainly one of the

handsomest men that I have seen in New Orleans.

His manners are charming, as I suppose they ought

to be, seeine that he has lived in Paris since he was a child."I

One last example might be given to show De Forest's use of combining the author's report and parlor conversation in presenting incidents seen by De Forest when he was stationed in Louisiana. De Porest often complains in his journal of the differences of the lot of the field officer and the garrison officer, such as in this passage:

Wren lieutenants secure quarters in fine dwellings, where they use the plate, drink the wine cellars dry, and in various ways spoil the Mgyptlans. Meanwhile we fleld regiments sleep in tents as hot as ovens and as leaky as sleves.2

On one occasion he dines with one of the colonels and passes the night with the colonel's adjutant. In relating this incident he remarks, "Of course I was not indignantly surprised to find the fleld officer grandly lodged and abounding in foraged claret. But I really was disgusted at receiving an even more luxurious hospltality from a mere lieutenant." 3

H1s description of the latter's house comprises one of the most interesting of De Forest's letters, and a good deal of this information he includes in his novel. An excerpt from this letter gives an ides of the quality of this description:

1. P. 187 .

2. P. 44 .

3. P. 48 . 
The adjutant's house is omall, but it is a treasure box. Bills found in a secretary prove that the furniture, all of Parialan make, cost fifteen thousand collars... One of the most valuable articles is a small bureau encrueted with patterns of gilt enamel set in tortoise shell.

Knicknacks lie about in profusion, such as Swiss boxes, dellcate rood carvings, amber-mouthed Turkish pipes, volumes of engravings, dress swords, old Toledo blades and inlaid pistols...

The adjutant told me the story of the vanished proprietor. He was a rich swell, of the old French colonial stock, who journeyed with his wife to Paris, and there fell in with an actress; the result being that the wife returned alone, while the husband and the parisienne followed in company. The wife got a separation in due time, and this pretty box was built for her successful rival. How the man is a captain in the hebel army, and the actress is petitioning our military governor for recovery of her wardrobe and other property.l

In the novel Lieutenant Van Zandt, partially under the influence of the wine from the cellars of this "elegant little box," entertains Doctor Ravenel as he waits for the arrival of Captain Colburne. As observant author De Forest says:

The Doctor...looked about the room and admired the costly furniture and tasteful ornaments. There were two cholce paintings on the paneled walls, and a dozen or so of choice engravings... The marble mantels and table, and the extravagant tortoiseshell tiroir, were loaded with Italian cameos, Parisian bronzes, Bohemian glass-ware, Swiss wood-sculpture, and other varieties of European gimcracks.2

Through the conversation of the loquacious Van Zandt, Doctor Ravenel and the reader discover the identity of the owner of the house:

"Elegant little box, sir," observed the lieutenant. "It belongs to a gentleman who is now a captain in

1. F. 48-9.

2. P. 129 . 
the rebel service. He built and furnished it for his affinity, an actress whom he brought over from Par1s, which disgusted his wife, I understand. Some women are devilish exacting, sir."l

As a sixth device, De Forest sometimes, although these cases are seldom, reconstructs or describes in detail a scene just as he has done in $\triangle$ Volunteer's Adventures, only inserting the characters of the novel or a mention of them wherever necessary. As in the examples quoted previously, De Forest does not use his original description verbatim, but changes it so that it will better lend itself to the structure of the novel. However, it should again be brought to the attention of the reader as it has been done once before, that in this, as in the five previous sets of examples, there is little or no fictionalizing. The changes which De Forest makes are not in elaboration of the incidents or events which he has noted in his letters or articles, but rather a change in presentation so that the various bits of Information will form a complete whole in the end.

De Forest says in his article on forced marches:

I have already said that we were en bivouac. Shelter tents were as yet unknown in the Department of the Gulf, and our wall tents, as well as every other article of not absolutely essential baggage, had been left at Brashear City. For cover, our servants made hasty wigwams or lean-tos of rails, over which we threw our rubber blankets to keep out the "heft" of the showers. If it rained we sat up with oud overcoats over our heads, or perhaps slept through it without minaing.2

1. P. 129 .

2. P. 97 . 
This description becomes in Miss Ravenel's Conversion:

In the early part of this month of Hay, 1863, we find him with his company, regiment and brigade, encamped on the bank of the Red River, just outside of the once flourishing little city of Alexandria, Louisiana. Under the protection of a clapboard shanty, five feet broad and ten feet high, which three or four of his men have voluntarily built for him, ho is lying... for since ho left his tent at Brashear City, four weoks previous, this is the first shelter which he has had to protect him from the rain, except one or two ticklish mansions of ralls, piled up by Henry...I

Another instance which can be cited refers to De Foreat's description of a deserted plantation which he notices around Brashear City in the winter of 1863:

To our right is the usual swampy forest of cypress, with its tall, grey, moss-hung trees; and in front of us is a deserted plantation, its wooden mansion and brick sugar-house shaded by evergreen oaks. The straggling, unprosperous, mouldy village is nearly deserted, and most of its dwellings are closed. A wlld March-like wind is rattling the shutters, shakdng the trees and dooryard thickets, and struggling to overturn our tents.2

Miss Ravenel and her father arrive at a similar plantation home,

which De Forest describes in oimilar terms:

The plantation house was a large, plain wooden mansion... An eighth of a mile away, not far from the winding road which skirted the simous base of the levee, was the most expensive building of the plantation, the great brick sugar-house, with vast expanses of black roof and a gigantic chimney. 3

Another of De Forest's interesting observations is treated

in a similar way in the novel. He says in one of his letters:

I. P. 275 .

2. P. 79.

3. $\mathrm{Pp} \cdot 252-3$. 
You would stare to see how little interest is aroused by the fact of a man being shot dead. Half a dozen gather to look at the body and promptly disperse to tell the tale to their comrades, who meanwhile have not left their bunks or their suppers. For a day or so the tragedy is discussed carelessly; there is a little blame and more praise for the sentry; then the regiment talks of other things.l

In the novel the same emotions are described as the dead and wounded fall:

Now and then a shriek or oath indicated that a bullet had done its brutal work on some human frame. No crowd collected; the men were hardened to such tragedies; four or five bore the victim away; the rest asked, "Who is iti"2

Equally interesting is De Forest's description of a field hospital. Although he describes hospital iffe in detail in the novel, he does not do the same in his letters or articles. The remarks on this subject which he makes in $\underline{A}$ Volunteer's Adventures, however, form the basis of most of the description in the novel. In part, he says in his description of his activities with Sheridan's army in the victory of the Opequon:

The scene in this swarming gorge was one not easily forgotten. The road was crowded with wagons, ambulances, gun carriages and calssons...Presently we met litters loaded with pallid sufferers, and pessed a hospltal tent where I saw surgeons bending over a table, and beneath it amputated limbs lying in pools of blood.3

In the novel Colburne is wounded and goes first to a fleld hospital, later to a station hospital. His wound is not grave, however, as De Forest's own was not, and it seems that the principal reason for hospitalizing Colburne is in order to describe

1. P. 80 .

2. P. 302 .

3. P. 173 . 
the horrors of the fleld hospital work. Prior to Colburne's coming to the fleld hospital, the author describes a scene of battle wounded and dead:

When Colburne came to himself he was lying on the ground in rear of the pieces.... dozen steps away, rapidy blackening in the scorching sun and sweltering air, were two more artillerists, stark dead, one with his brains bulging from a bullet-hole in his forehead, while a dark claret-colored streak crossed his face...1

Shortly after Colburne recovers from the shock of being wounded, Ileutenant Van Zandt appears and the two men walk slowly to the rear in search of a fleld hospital. Deep in the woods, a mile and a half from the front, they come to the field hospital of their division:

It was simply an immense collection of wounded men in every imaginable condition of mutilation, every one stained more or less with his own blood, every one of a ghastly yellowish pallor, all lying in tho open air on the bare ground, or on their own blankets, with no shelter except the friendly follage of the oaks and beeches. In the centre of this mass of suffering stood several operating tables, each burdened by a grierously wounded man and surrounded by surgeons and thoir assistants. Underneath were great pools of clotted blood, amidst which lay amputated fingers, hands, arms, feet and legs, only a little more ghastly in color than the faces of those who waited tholr turn on the table. The surgeons, who never ceased their awful labor, were daubed with blood to the elbows; and a smell of blood drenched the stifling air, overpowering even the pungent odor of chloroform.2

The foregoing passage might well be one of the reasons that the public did not readily take to De Forest. The reading public of this period consigted mostly of young ladies, and young ladies

I. P. 289.

2. P. 292 . 
wanted their battles more herolc, less bloody. The picture of amputated fingers and toes lying in pools of clotted blood below the operating table is, perhaps, too sickening for even some of the readers today, as the reaction to Irwin Shaw and Frnest Hemingway might suggest.

A serenth derice used by De Forest is reconstruction of events in the novel which originally befell De Forest when he saw service with the Union army. Although De Foreat does not fictionalize these ovents which he literally transplants from his earlier papers into his Civil War story, he does alter such facts as time of day, location of place, and names of participants in order to make the incident he is describing fit in with other elements of the plot. Sometimes the events he reconstructs are of such minor inportance, the reader almost overlooks the fact that De Forest is using a true incident. For example, in his article on forced marches he says:

After a breakfast of hardtack and coffee, I dozed a few minutes while the fall-in call was beating, and then set off on a day's march of twenty-seven miles, coming in after nightfall well blistered.l

Apparently this is the source for this pasage in the novel:

At five o'clock on the morning of the 27th of May, Colburne was awakened by an order to fall in. Whether it signified an advance on our part....he did not know nor ask, but with a soldier's indifference proceeded to form his compeny, and, that done, ate his breakfast of raw pork and hard biscuit. 2

Or again, in another article, he says:

The lieutenant colonel yelled repeatedly, "Centre 
dress! Close up those gaps! Centre dress!" The company officers yelled also, repeating the same orders. In our inexperience we believed that everything was lost if the men did not march shoulder to shoulder; and all through the battle we labored to keep a straight line with a singlemindedness which greatly supported our courage.l

This peculiar attempt to drill during battle is noted in the novel:

At last the Lieutenant-Colonel's voice rang out. "Battalion, forward. Guide right. Narchl"

To keep the ranks closed and aligned in any tolerable fighting shape... was a task of terrible difficulty.2

Another minor incident which De Forest inserts in his novel has its source in one of his articles. He comments in his account of the battle at Port Eudson; "My sergeant, Weber, shook the man next him and discovered that he was stone dead, perhaps killed in his sleep." 3 In the novel. Doctor Ravenel observes a man lying in a gully, his eyes wide open and fixed upon the palisede, his right hand loosely holding a rifle:

"Would you be good enough to lend me your gun for a few momentsi" he inquired.

The man made no reply; he was perfectly dead. 4

In the same article on Port Fudson, De Forest records another incldent which is incorporated in the narrative of Miss Ravenel's Conversion with little change. He often remarked on the merciless climate of the berou region of Louisiana, and in this instance, says:

The dead man who was brought in to us was a horrible spectacle, swollen and perfectly black with putrefaction, filling our bivouac with an insupportable odor. 5

1. P. 60 .

2. P. 280 .

3. Pp. 141-2.

4. P. 337 .

5. P. 132 . 
In the novel the author describes an undentified officer who die from a bullet wound in his thigh:

In an hour more he was a corpse, and before night he was black with putrefaction, so rapid was that shocking change under the heat of a Louisiane May.1

In more detail, De Forest, in his account of the attack on Port Eudson, narrates the building a breastwork of logs, and of the men's prowess in markmanshlp from behind this breastwork:

We laid a line of logs along the crest of the knoll, cut notches in them, and then put on another tier of logs, thus providing ourselves with portholes. With the patience of cats watching for mice the men would peer for hours through tho portholes, walting a chance to shoot a Rebel...

After the wrender an officer of the Second Alabame told me that most of their casualties were cases of shots between the brim of the hat and the top of the head; and that having once held up a hoe handle to test our marksmanship, it was struck by no less than three bullets in as many minutes.2

This description is reconstructed in Miss Ravenel's Conversion to read:

The Tenth occupied a little hollow about one hundred and fifty yards from the rebel fortifications, protected in front by a high knoll, but exposed on the left to a fire which hit one or more every day. The men cut a terrace on their own side of the knoll, and then topped the crest with a double line of loge plerced for musketry, thus forming a solid and convenient breastwork... On both sides the marksmanship grew to be fatally accurate... After the siege was over, a rebel offlcer, who had been stationed on this front, stated that most of his killed and wounded men had been hit just above the line of the forehead. 3

1. P. 294 .

2. P. 118.

3. Pp. 301-2. 
Two more devices should be noted which De Forest uses in transferring into fiction the materials he gathered as a Unton officer in the Southwest campign of the Civil War. One of these is his use of actual place names and actual personal names in real life situations. The second is his use in the novel of figures of speech and images which he originally used in his letters and articles, and which are particularly descriptive and characteristic of his style of writing.

of the first device, examples are too muerous to name at this time in illustrating the use of place names and personal names in the novel. Framples which have been utilized on previous pages to illustrate other points contain examples of this point also. The narratives of both books follow much the same course in naming battles, places of duty, and campaign areas. It is, of course, logical that the novel would, In dealing with this particular section and course of the war, contain the same place names as De Torest's journal. It is also only logical that he would use the names of the Union commanders, such as Generals Banks, Weitzel, Butler, and Phelps, and the Confederate commanders, such as Taylor, Greene, and Mouton, who figared in these bettles. As for the use of images and figures of speech found in both books, the most notable ones are De Forest's word sound descriptions of the rarious kinds of battle artillery. In $A$ Volunteer's Adventures he speaks of these distinctive sounds, using such 
1

terms as the "pum--pum of cannon," the "spang of the brass twelvo-pounders, " the "whit-whit of rifle bullets, ${ }^{3}$ and the

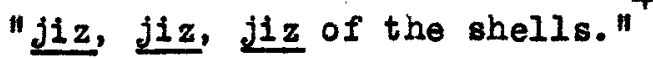

These word-sound colnages are used again in Miss Ravenel's

Conversion. At one time, the author reports:

The battle had already commenced, although Colburne could see nothing of it, and could hear nothing but a dull pum-pum-pum of cannon. 5

Agaln, in describing Colburne's adventures, the novel roads:

In a minute the two brass Napoleons opened with a sonorous spang, which drew a spontaneous cheer from the delighted infantry. 6

Another of De Forest's word sounds appears in this excerpt from the novel:

In reply, similar fiery spittings scintillated from the dark mass of the fort, and there was a rapid whit-whit of invisible missiles.7

Similarly:

The dead were falling;...the leisurely hum of longrange bullets had changed into the sharp, multitudinous whit-whit of close firing; the stifled crash of balls hitting bones, and the soft chuck of flesh wounds mingled with the outcries of the sufferers...8

It is regrettable that De Forest did not use in the novel the nost memorable 1mage in the historical record:

It was not a volley but a file fire; it was a contimous rattle like that which a boy makes in running a stick along a picket fence, only vastiy louder...9

1. Pp. 108, 120, 175 .

2. P. 110.

3. Pp. 62, 215.

4. P. 87 .

5. P. 281 .
6. P. 283.

7. P. 333 .

8. P. 455 .

9. P. 62 . 


\section{CEAP TIFR $\nabla$}

CONCLUSION

Until 1939 when Miss Ravenel's Conversion was re-published by Earper and Brothers, John William De Forest was generally ignored by the literary historians who sought to trace the advance of realism in the American novel. With most of his novels out of print for over half a century, and his master-plece, Miss Ravenel's Conversion, out of print for seventy years; with $A$ Volunteer's Adventures, a record of his Civil War experiences, unpublished until 1946, and $\mathrm{A}$ Unlon Officer in the Reconstruction unpublished until 1948. it is little wonder that few were familiar with his name. Recognition of De Forest's achievenents has come, however, since 1939 from such worthy critics as Carl Van Doren, Van yck Brooks, and Alexander Cowle. The generous and enthusiastic reviews given De Forest's novels by WIIliam Dean Howells have been resurrected and quoted liberally by the critics.

Since it has taken so long for De Forest to gain recognition for his achievements, naturally little research has been done on either him or his works. This paper has been an attenpt to show that De Forest used the papers, articles, and other records he kept when he was an officer in the Union army in writing his novel, Miss Ravenel's Conversion. Only tnose records appearing in $\underline{A}$ Volunteer's Adventures were used in making the comparisons. Through an exhibition of similar passages appearing in the two books, it has been pointed out that De Forest evidently used 
the historical record for describing characters, backgrounds, and settings in the novel; and especially apparent is De Forest's use of actual incidents during his military career. The large number of these examples establishes the fact that De Forest used the same material in both books.

The primary purpose of this paper, however, is to show exactly the methods which De Forest used in translating his war experiences into fiction. The methods were catalogued and it was found that he used the following devices: letters, paraphrasing of letters, report of events by the observant author, conversation, combination of conversation and report by the observant author, reconstruction of events, reconstruction of scenes, use of actual place names and personal names, and the use of figures of speech and images first used in his letters and articles.

Although this paper has not dealt specifically with the problem of fictionalization, it has been indicated several times that De Forest, in translating his war experiences into fiction, did not attempt to heighten the enotional appeal of a particular story or event by elaboration of detalls, by insertion of half-truths, or by insertion of false details. Incidents appearing in both books are given the same treatment. Alterations in stories or incidents appearing in A Volunteer's Adventures are found in Miss Ravenel's Conversion only when a detail of the story must be changed in order to agree with information previously given in the novel, such as names of characters or the time of day. Although there is no way of checking on how truthfully De Forest described his war experiences 
in the original papers, it is only fair to assume that he reported them as exactly as he was able, since this was his avowed purpose.

If realism be defined as a true or actual report of that wich comes under the author's observation, artistically rendered, then John William De Forest can be declared a realistic writer, as this paper has undertaken to indicate that De Forest used actual records in writing his novel. The realism detected in De Forest's novels by William Dean Howells is, in reality, his ability to observe accurately and record conscientiously his life experiences.

The results would Indicate that De Forest depended on actual experience in writing fiction. It is a curious fact that he has done much the same thing which he did in Misg Ravenel's Conversion in several of his other novels. Although it is outside the scope of this paper to investigate De Forest's use of letters and records of his other life experiences in writing novels other than Miss Ravenel's Conversion, perhaps some one else will undertake to study the similarities between Irene the Missionary and Oriental Acquaintance, and the similarities between either The Bloody Chasm or Kate Beaumont and A Union Officer in the Reconstruction.

1. A Volunteer's Adventures, p. xriii. 


\section{BIBLIOGRAPHY}

\section{BOOKS}

Baker, Irnest A., A Guide to the Best riction in Mnglish, New Idition, London: George Routledge and Sons IImited, 1913, p. 408 .

Brooks, Van Wyck, New Ingland: Indian Summer 1865-1915, New York: E. P. Dutton and Company, Inc., 1940, Chapters XI and IV.

Cowie, Alexander, The Rise of the American Novel, Now York: American Book Company, 1948, Chapter XII.

De Forest, John W., The Bloody Chasm, New York: D. Applet on and Company, 1881 .

Loyalty, New $\frac{\text { Miss }}{\text { Bark: }} \frac{\text { Barenel's }}{\text { Harper and }} \frac{\text { Conversion }}{\text { Brothers, }} \frac{\text { from Secession to }}{1867}$

Misg Ravenel's Conversion from Secession to

Loyalty, New York: Harper and Brothers, $\overline{1939 .}$

Orlental Acquaintance; or, Letter from Syria,

New York: Dix, Fdwards, and Company, 1856.

A Union Officer in the Reconstruction, New Haven, Connecticut: Yale University Press, 1948.

A Volunteer'g Adventures, New Baven, Connecticut: Yale University Press, 1946.

Fullerton, B. M., Selective Bibliograghy of American Literature

1775-1900, New York: Dial Press, 1936, pp. 81-3.

Hart, James D., The Oxford Oompanion to American Iiterature, Iirst Bdition, New York: Oxford University Press, 1944, p. 185.

Howells, William D., Heroines of riction, New York: Harper and Brothers, 1901, 701. 11, pp. 152-63.

Brothers, 1895, $\frac{\mathrm{pp} .}{223-4 .}$

Hy Literary Passions, New York: Harper and 
Johnson, Allen, and Malone, Dumas, editors, Dictionary of Amer1can Biography, New York: Charles Scribner's Sons, 1930, จ01.

Leonard, John W., editor, Who's Who in America 1906-07, Chicago: A. H. Karquis and Company, 1907, p. 455.

McIlwaine, Shields, The Southern Poor-White from Lubberland to Tobacco Road, Norman, Oklahoma: University of Oklahoma Press, 1939. Chapter III parts I and II, and Chapter IV part VI.

The National Cyclopaedia of American Biography, New York: James T. White and Company, 1893, vol. iv, p. 293.

Spiller, R. I., Thorp, W., Johnson, T. H., Canby, H. S., editors, Iiterary History of the United States, New York: The Wacmillan

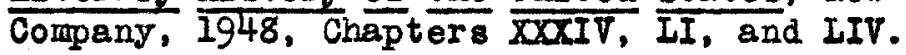

Trent, W. P., \#rsidine, J., Sherman, S. P., Van Doren, Carl, editors, The Cambridge History of American Literature, New York:

The Macmillan Company, 1943, Chapter XI.

Van Doren, Carl, The American Novel 1789-1939, New York: The Nacmillan Company, 1940, Rev1sed idition, Chapters VII and XII.

W1lson, J. G., and Fiske, John, editors, Appletons' Cyclopaedia of Anerican Blography, New York: D. Appleton and Company, 1888, vol. 1 i, p. 123.

\section{PIRIODICAIS}

"Connecticut Yankee," Pime, vol. xlvi11, July 22, 1946, p. 99.

Gordon, Clarence, "Mir. De Forest's Novels," The Atlantic Konthly, vol. xxxi1, November, 1873, pp. 611-21.

Howello, Willam D., "Recent Iiterature," The Atlantic Monthly, vol. xuxr, February, 1875, p. 238. (A review of Honest John Vane.)

"Recent Iiterature," The Atlantic Monthly, vol. xxix, March, 1872, pp. 364-5. (A review of Kate Beaumont.)

"Reviews and Ilterary Notices," The AtIantic Monthly, vol. xx, July, 1867, pp. 120-2. (A review of Miss Ravenel's Conversion from Secession to Loyalty.) 
"Recent Iiterature," The Atlentic Monthly, vol. xxix, January, $1872, p .111$. (A review of overland.)

"Recent Literature," The Atlantic Monthly, vol. xxaiv, August, 1874, pp. 229-30. (A review of The Wetherel Affair.)

"Some Heroines of Fiction," Harper's Bazar, vol. $x \times x v$, October, 1901, pp. 538-44.

"Neglected Giant," Time, vol. 11, May 24, 1948, pp. 106, 109-10.

Perry, T. S., "American Novels," The North American Review, vol. cxv, October, 1872, pp. 366-78.

"Rebel Romance," Time, rol. xxxtr, August 21, 1939. pp. 57-9.

Sedgwick, A. G., "A Novel of the Rebellion," The Nation, vol. xxxi11, November 10, i881, pp. 376-7.

\section{ONHIRS}

Croushore, James H., John William De Forest, A Biographical and Critical Study to the Yosr 1868 , unpublishod doctoral

dissertation, Yale University, Hew Haven, Connecticut, 1943.

De Forest, John W., Honest John Vane, published serially in

The Atlant1c Monthly, vol. $x \times x i 1$, July to November, 1873.

Kate Beaumont, published serially in

The Atlantic Monthly, vols. xxil and xxvili, January to Decenber, $187 \overline{1 .}$

Overland, published serially in The Galaxy, vols. $x, x 1$, and $x i 1$, August to December, 1870 , and January to July, 1871 .

The Wetherel Affair, published serlally in

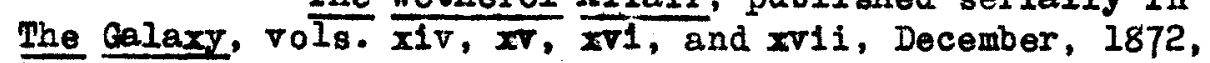
January to June, 1873, July to December, 1873, January, 1874. 